\title{
Modeling on climate induced drought of north-western region, Bangladesh
}

\author{
Khandaker Masudur Rahaman' ${ }^{1}$ Fazle Rabbi Sadeque Ahmed ${ }^{2} \cdot$ Md. Nazrul Islam $^{3}$
}

Received: 2 February 2016/Accepted: 4 February 2016/Published online: 10 March 2016

(C) Springer International Publishing Switzerland 2016

\begin{abstract}
Climate change has occurred naturally over time due to conditional drift, cosmological cycle and changes in volcanic activity and solar energy. Industrial revolutions have changed the balance of natural equilibrium of earth's climate constituent, making atmosphere warmer than its natural rhythm eventually causing catastrophic consequences on geographically vulnerable countries, which is an established fact by several international organizations including IPCC. Among the vulnerable countries, Bangladesh is facing increasing trend of climatic hazard along with extreme super event. North-western region of Bangladesh is mostly vulnerable to drought. Within the last two decades (1994-2013), annual average maximum temperature has increased by $0.16{ }^{\circ} \mathrm{C}$ and the average minimum temperature is forecasted to be increased by $1.3{ }^{\circ} \mathrm{C}$ at the end of this century considering the four decadal (1964-2013) trend. Over the last two decades i.e. 1994-2003 and 2004-2013, the annual average rainfall has calculated 151.50 and $138.09 \mathrm{~mm}$, respectively. Rainfall has decreased quite significantly in the last decade. From 1995 humidity level is found to be static in nature. Northwestern region is an important agricultural hub of Bangladesh. Decrease in rainfall and its seasonal variability have made the region more dependent on ground water for irrigation. Spatial and trend analysis shows groundwater depletion trend is getting steeper in this region. On the
\end{abstract}

Khandaker Masudur Rahaman

khandakeropu07@gmail.com

Org-Quest Research Limited, Dhaka-1215, Bangladesh

2 Community Climate Change Project (CCCP), Palli KarmaSahayak Foundation (PKSF), Dhaka, Bangladesh

3 Department of Geography and Environment, Jahangirnagar University, Savar, Dhaka-1342, Bangladesh other hand, surface water level for every district, except for Pabna, shows negative skewedness. Increasing trend in maximum temperature stimulating high evaporation as well as uncertainty of trans-boundary water movement is found to be strongly influencing the depletion of surface water level. These circumstances are making North-western region more vulnerable towards drought.

Keywords Climate change - Climate-induced drought . Barind region - Surface water level and Ground water level

\section{Introduction}

Now a day's climate change issue is an established fact and the Intergovernmental Panel on Climate Change (IPCC) has also accepted it and accuses this as a threat to sustainable development (Fatima Denton 2013). Climate change can be defined as a trend or persistent change in the state of the climate that includes amongst others properties such as temperature, precipitation, humidity and wind speed (Haji 2011). Variation of the climatic indicators such as temperature; precipitation, relative humidity, wind speed etc. are varied based on spatiotemporal distribution, and also on the economic activity, land use change, vegetation coverage and spatial distribution of water bodies such as river and ocean.

Climate change has a direct and indirect effect on water resources. Some study has detected significant change in some indicators of river flow, and some have demonstrated statistically significant links with trends in temperature or precipitation (Bates 2008). Disparity in river streams from year to year is also subjective in some regions by largescale atmospheric circulation patterns and other variability systems that function at within-decadal and multi-decadal time-scales. 
Despite the fact, less than $1 \%$ of the world's fresh water (or about $0.007 \%$ of all water on earth) is readily accessible for direct human use. Depletion of this invaluable resource continues without regard for the future (Haji 2011). As a consequence of continued failures by international community in safe guarding water resources, coupled with increasing poverty and inequality, 1.1 billion people (approximately one in six people on earth) lack access to an improved water supply (Watkins 2006). Over the last century, water use has grown at twice the rate of population growth. UN-WATER predicts approximately 1800 million people will be living in countries or regions with absolute water scarcity (UN-WATER 2007), and twothirds of the world population could be under water stress conditions by Year 2025 (Haji 2011). As it is predicted and sometime statistically proved that, there exists or will be exists water stress, in another word, possibility of occurrence of drought.

\section{Research problem}

Floods, cyclone, storm surge, drought are natural phenomenon, among them drought is caused by the disturbance of water cycle. There are different kinds of drought, among them, hydrological drought includes both surface water and ground water drought, and which occurs due to deficiency of surface water as well as sub-surface water.

Every year, Bangladesh experiences a dry period for 6 months (November-April) when precipitation is normally low. Bangladesh has already experienced an increased frequency of drought in recent years (Adhikary et al. 2013). It is a recurrent phenomenon in some parts of the country, but the northwestern region is severely drought prone because of the high variability in rainfall (Shahid and Behrawan 2008). All the rivers and cannels of this area dry up during the dry season, and make the people completely dependent on ground water, especially for irrigation. About $75 \%$ water for irrigation in the region comes from ground water (Bari and Anwar 2000).

Very few studies have been found on drought of northwestern region. Among the studies almost none of the study has considered the whole water cycle for the availability of water in natural water source. Most of the study blamed ground water extraction, mainly for irrigation purpose under the Barind irrigation project. Some studies has considered precipitation rate. But no study has considered the flow of surface water. Surface water sources have significant influence on revitalization of ground water aquifer. This study has considered most of the element of water cycle to explore the hydrological drought and climatological drought phenomenon as, ground water and surface water source and rainfall rate. This study also explored the trend of annual average maximum temperature, annual average minimum temperature, annual average mean temperature, trend of annual mean relative humidity and their influence on rainfall.

\section{Broad objective of the study}

The purpose of the study is to explore the impacts of climatic indicators on water resources of northwestern region of Bangladesh.

\section{Specific objective of the study}

\section{To explore the trend of seasonal climatic indicators (Temperature, Rainfall, Relative humidity) of north western region}

1. Spatial and temporal analysis of annual mean maximum temperature.

2. Spatial and temporal analysis of annual mean minimum temperature.

3. Spatial and temporal analysis of annual mean temperature.

4. Spatial and temporal analysis of annual mean rainfall.

5. Spatial and temporal analysis of annual mean relative humidity.

To explore the changing pattern of surface water level and ground water level of north western region

1. Spatial and temporal analysis of ground water table depth.

2. Temporal analysis of surface water level.

3. Exploring the revitalization impact of annual mean rainfall rate on ground water level and surface water level.

\section{Literature review}

From the beginning of the Earth, climate is changing, so it's a natural phenomenon. Natural causes of climate change are such as biotic processes, variations in solar radiation received by Earth, plate tectonics, and volcanic eruptions. But if the climatic indicators are change by force of any external episode then it became a concerning issue. In recent decades the changing pattern is not in its harmonic pattern rather it is becoming more rough and fast with extreme natural event. Scientists are accusing human activity for this. Certain human activities have also been 
identified as significant causes of recent climate change, often referred as "global warming".

According to Oxford Dictionary climate change can be defined as, "changes in the earth's weather, including changes in temperature, wind patterns and rainfall, especially the increase in the temperature of the earth's atmosphere that is caused by the increase of particular gases, especially carbon dioxide."

The Framework Convention on Climate Change (UNFCCC), in its Article 1, defines "climate change" as: "a change of climate which is attributed directly or indirectly to human activity that alters the composition of the global atmosphere and which is in addition to natural climate variability observed over comparable time periods". The UNFCCC thus makes a distinction between "climate change" attributable to human activities altering the atmospheric composition, and "climate variability" attributable to natural causes.

Bangladesh is a little deltaic country located in South Asia, which consists of 147,570 sq.km area with $149,772,364$ population (BBS 2011). It is referred by many study and as well as IPCC and World Bank that the country would most likely to be harshly affected by climate change issues. The anticipated changes in hydrological regime would accentuate high intensity climatic events (Ahmed 2005). Third Assessment Report of the IPCC also ranked Bangladesh high in the list of most vulnerable countries (IPCC W. 2001). According to Fourth Assessment Report of IPCC (IPCC W. I. 2007), several evidences of climate change and its impacts are already visible in Bangladesh: as Average temperature has increased by about $1{ }^{\circ} \mathrm{C}$ in May and $0.5^{\circ} \mathrm{C}$ in November during the 14 year period from 1985 to 1998; decadal rain anomalies were found to be above long term averages since 1960s; Serious and recurring floods have taken place during 2002, 2003, and 2004. Cyclones originating from the Bay of Bengal have been noted to decrease since 1970 but the intensity has increased; Frequency of monsoon depressions and cyclones formation in Bay of Bengal has increased; Salt water from the Bay of Bengal have penetrated $100 \mathrm{~km}$ or more inland along tributary channels during the dry season; and precipitation has decline in some areas of Bangladesh and droughts has resulted in the drying up of wetlands and severe degradation of ecosystems.

The IPCC reported that climate change is very likely to cause higher maximum temperatures, more intense precipitation events, increased risk of drought, increase in tropical-cyclone peak wind intensities, and an increasing number of floods in some areas (IPCC W. I. 2007). Many of the studies have found clear evidence of change in major climatic indicator such as temperature and rainfall over the last few decades, as Agrawala et al. considering 2003 as base year, have predicted that the annual mean temperature will increase from baseline $1.0^{\circ} \mathrm{C}$ in 2030 to 1.4 and $2.4^{\circ} \mathrm{C}$ by the year 2050 and 2100; (Agrawala et al. 2003); IPCC also predicted that the Monsoon rainfall is expected to be increased by another 11 and 27 per cent by the year 2030 and 2070 respectively; According to Climate Change Cell during the post-monsoon to pre-monsoon cycle, rainfall diminishes while temperature increases and so on (Ahmed 2006). It is reported that Bangladesh has been experiencing significant variation in its annual and seasonal rainfall patterns from last several years the mean maximum and minimum temperature is also increasing gradually (IPCC 2001; Ahmed 2006).

Not only the unique geographical location and its climatic nature has made Bangladesh vulnerable but also some man made and regional reason like as building Farakka Damp by the neighboring country India, deforestation, filling up river such activities reducing the countries adaptive capacity. Continued deforestation in the upper catchment areas of the Ganges-Brahmaputra-Meghna basins (GMBs) has increased sediment deposition on the river beds in the downstream, leading to reduced drainage capacity and increasing flood vulnerability of Bangladesh. All these observed changes have adversely affected the agro-ecosystems of the country (Neelormi 2008).

Drought is being considered as the main cause which hampers the estimated agricultural production, here in Bangladesh over the last few decades. Causes of drought in Bangladesh are, shortage of surface and subsurface water resource and climate variability, lack of precipitation may be due to large-scale downward air movement within the atmosphere or absence of available moisture in the atmosphere which suppresses rainfall, local level causes are human-induced changes resulting from vegetation loss due to over exploitation of resources and deforestation.

\section{Linkage between climate change and water resources (ground water and surface water)}

Climate change can change the spatiotemporal distribution of precipitation, runoff, soil moisture and water level of lakes etc. and thus therefore impact the groundwater circulation and spatiotemporal distribution of water resources (UNESCO-CCPF 2011). As many ground water both changes into and are recharge from surface water, impacts of surface water flow regimes are expected to affect groundwater. Increased precipitation variability may decrease groundwater recharge in humid areas because more frequent heavy precipitation events may result in the infiltration capacity of the soil being exceeded more often (Bates 2008).

The relation among groundwater, climate and human activities as well as the supply for groundwater are more 
complicated then surface water, and the response to climate change is slower than surface water, so the interaction among them based on long-term observation data of precipitation, temperature and groundwater level is very crucial. The impact of precipitation change on groundwater replenishment can be shown through change of river base flow (quantity of river for groundwater replenishment) (UNESCO-CCPF 2011). Decreasing surface water flow increases the demand of ground water, especially in drought prone areas, which also demonstrate the indirect impact of climate change on water resources.

Climate change has a series of impact on hydrologic cycle. Increasing temperature will change the quantity of precipitation and will also increase the proportion of ice melt. Rising temperature will stimulate evapotranspiration which leads to drier soil and less surface water. Hot weather holds gas more than water and also hampers the condensation process. As a result the evaporated water flies away from the region to elsewhere. Increasing concentration of $\mathrm{CO}_{2}$ will affects the vegetation due to evapotranspiration. Excessive heat affects the moisture holding capacity of soil.

The above phenomenon may cause longer drought, which will alter the land cover thus affecting catchment run off response to precipitation. Furthermore, ground water recharge will also be affected thus changing the quantity of percolation. This change will consequently alter the base flow contribution of ground to stream flow (Haji 2011). Surface water also contributes to recharge ground water aquifer. Groundwater flow in shallow aquifers is part of the hydrological cycle and is affected by climate variability and change through recharge processes (Chen 2002). Ground water may also be depleted because of over extraction where increased groundwater withdrawals have been caused not only by increased water demand but also because of a climaterelated decreasein recharge from surface water supplies (Australia 2003).

\section{Research strategy}

This study is mainly based on quantitative approach. This study has tried to explore the inter-action or reaction or impacts of climatic indicators change (mean maximum temperature, mean minimum temperature, mean annual temperature, and mean rainfall and relative humidity) on the water resources (surface water and ground water) of northwestern region of Bangladesh which is making this region more vulnerable towards drought and their probable economic and environmental impact.

\section{Selection of study area}

The study area of this study is the Barind region of Bangladesh, which is situated north western side of Bangladesh (Fig. 1). The area consists of sixteen district, among them different climatic indicators of five districts (Bogra, Dinajpur, Pabna, Rajshahi, and Rangpur) were critically analyzed. These five districts were selected based on their geographical distribution, which are expected to represents the geographical characteristics of whole north western region. The selected districts are also under the irrigation development project of Barind Multipurpose Development Authority (BMDA).

\section{Approach of the study and data sources}

For attaining the objectives of this study quantitative analysis has done, based on secondary data. For attaining the first objective, 50 years (1964-2013) climatic indicators data of five selected district has been collected from Bangladesh Meteorological Department. Monthly ground water level data of different well and daily surface water level has been collected from the hydrology department of Bangladesh Water Development Board.

\section{Methods and techniques of data analysis}

Trend analysis of the climatic indicators has done by using Microsoft Excel. From the monthly maximum and minimum temperature data, annual average maximum temperature and annual average minimum temperature data has calculated. To analyze the decadal variation the data has also converted to decadal form. Monthly ground water data and daily surface water data has cleaned and normalize to calculate seasonal and annual data.

Spatial analysis of climatic indicator and ground water level has done by Geographic Information System-version 10.1 software. The X, Y coordinate of the well and weather station has converted to point feature. Then interpolation of Geo-statistical analysis has applied to analyze the spatial variation of climatic indicators and changes of ground water level of the selected districts well of north western region.

For analyzing spatial variation of climatic indicators and to explore their interaction, deterministic interpolation technique, Inverse Distance Weighted (IDW) has been applied (because directional influencing factor as wind data was unavailable so has not considered). IDW interpolation based on the assumption that things are close to one another are more alike than those that are farther apart. 


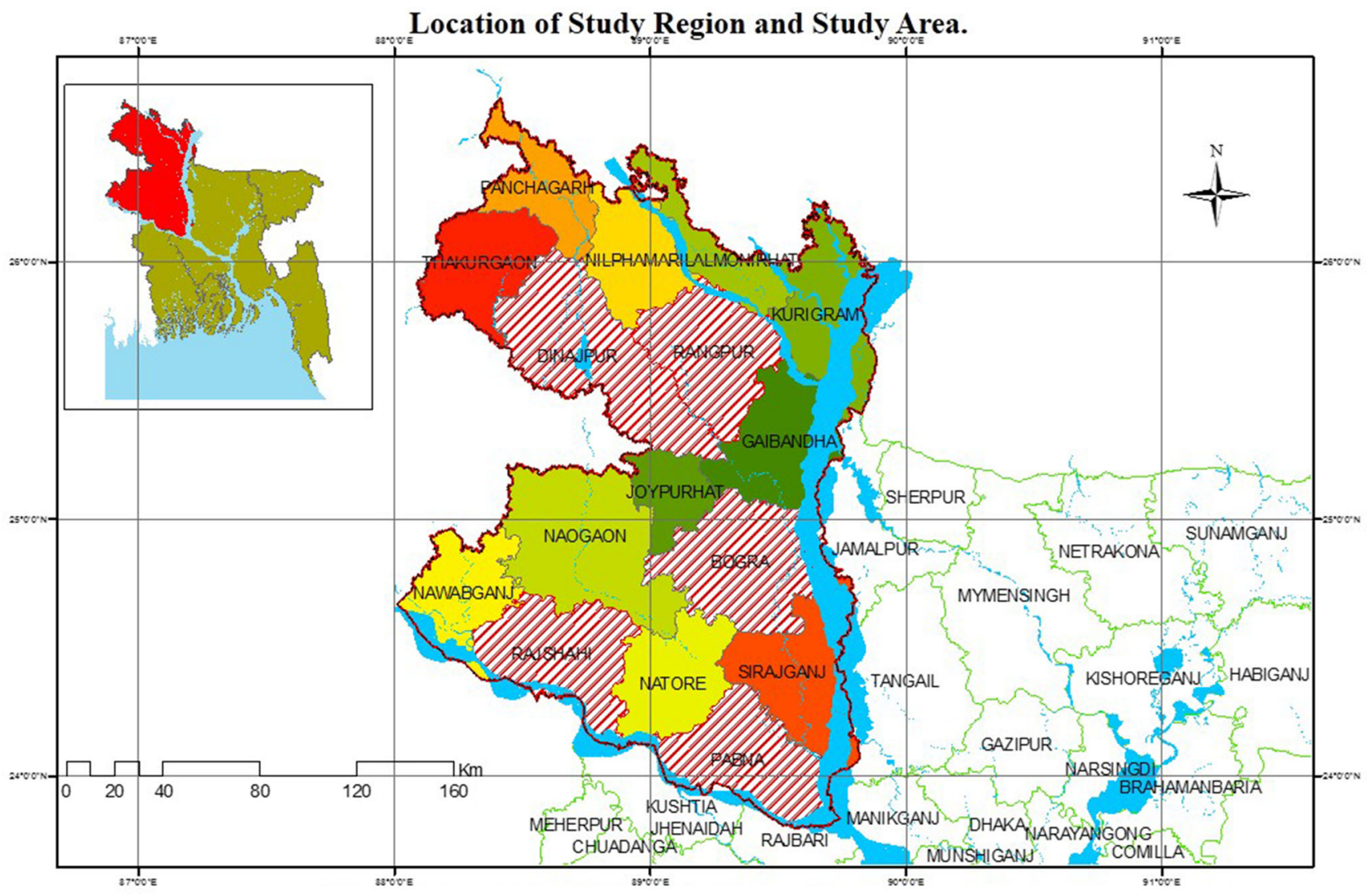

Fig. 1 Location of study region and study area

Thus IDW undertakes that each measured point has a local influence that reduces with distance. The formula is (Kevin Johnston 2003);

$Z\left(s_{o}\right)=\sum_{i=1}^{N} \lambda_{i} Z\left(s_{i}\right)$

where: $Z\left(s_{o}\right)$, the values we are trying to predict for location $\mathbf{s}_{\text {o. }} \mathrm{N}$, number of measured sample point. $\lambda_{i}$, the weights assigned to each measured point that we are going to use and inversely related with distance. $Z\left(s_{i}\right)$, the observed value at the location $\mathbf{s}_{\mathbf{i}}$

The weight deterministic formula of $\lambda_{i}$ is;

$\lambda_{i}=\frac{d_{i 0}^{-p}}{\sum_{i=1}^{N} d_{i 0}^{-p}}, \sum_{i=1}^{N} \lambda_{i}=1$

As the distance became larger, the weight is reduced by a factor of $P$. The optimal $P$ value is determined by minimizing the root-mean-square prediction error. $d_{i \mathrm{o}}$, the distance between the prediction location, $S_{o}$ and each of the measured locations $S_{i \text {. }}$.

So according to the above equation as the distance increases between the measured location and the prediction location, the influence that the measured point will have on the prediction will decrease exponentially. And the weights for the measured locations that will be used in the prediction are scaled so that their sum is equal to 1 .

For analyzing the changing (1985-2000) pattern of ground water table depth and to explore the influence of surface water source to revitalize ground water sources Ordinary Kriging of Geo-statistical interpolation has been applied. Though human activity (mainly for agriculture purpose) has direct influence of ground water degradation so it is not only necessary to predict the surface but also the error or the uncertainty of surface and the direction of uncertainty (anisotropy) and indication how good the prediction are. Ordinary kriging assumes the model,

$Z(s)=\mu+\varepsilon(s)$

where $\mu$, Constant and $\varepsilon(s)$, the error with $\mu$ constant or trend.

Ordinary kriging can use either semivariograms or covariance's, it can use transformation and remove trends and it allow for measurement error. So an appropriate transformation, a possible detrending surface, covariance/ semivariogram models are important parameters.

The semi-variogram and covariance functions quantify the assumption, that things nearby tend to be more similar than things that are farther apart and measures the strength of statistical correlation as a function of distance. The function is; 
$\gamma\left(s_{i}, s_{j}\right)=\frac{1}{2} \operatorname{var}\left(Z\left(s_{i}\right)-Z\left(s_{i}\right)\right.$

The above function describes, in terms of the distance measured of $\mathrm{d}\left(S_{i}, S_{j}\right)$, then they are expected to be similar and so the difference in their values, $Z\left(s_{i}\right)-Z\left(s_{j}\right)$, will be small and vies-a-versa.

Covariance is just a scaled version of correlation, and the covariance function is;

$C\left(s_{i}, s_{j}\right)=\operatorname{var}\left(Z\left(s_{i}\right)-Z\left(s_{i}\right)\right.$

Which also describes two locations, $S_{i}, S_{j}$ close to each other, then they are expected to be similar, and so their covariance will be large and as the location gets farther their covariance becomes zero.

The semivariogram/Covariance cloud has used to investigate autocorrelation among the data set. Spatial autocorrelation may depend only on the distance between two locations, which is called isotropy. If a pair of point that are close together means less $\mathrm{X}$-axis value should have less difference means low $\mathrm{Y}$-axis value, which is the assumption of geo-statistical method. For this study to ensure normal distribution of data all the data (of individual region) has transformed with $\log$. And with semivariogram cloud it is justified that there exists spatial autocorrelation as the north-western region is basically a plain region then it so certain that there will be spatial autocorrelation.

For analyze the surface water level, Box \& Whisker plot has analysis has done, through this technique it is possible to observe the whole year surface water level such as maximum water level, minimum water level and average water level of a selected year.

As the data sets are time period data so it was difficult to maintain the interval period, for this dissertation 5 years interval has considered. Therefore, in some graphs the time interval may be more than 5 years. Fifty years of time series data has divided in five decade as 1st decade (1964-1973), 2nd decade (1974-1983), 3rd decade (1984-1993), 4th decade (1994-2003) and 5th decade (2004-2013). Mainly multiple graphs has used for comparing rainfall and ground water table depth and comparison of surface water level and rainfall. Finally based on the findings of above analysis, possible economic and environmental impact of drought and conclusion was drawn.

\section{Analysis and discussion}

Five districts were selected for analysis and discussion. Analysis and discussion for each district was segmented into three parts, where first part includes temporal and spatial analysis of climatic indicators. Second part includes temporal and spatial analysis of ground water level and finally third part includes temporal analysis of surface water level.

\section{Analysis of temperature}

\section{Trend of annual average maximum temperature}

Figure 2 shows the ascending trend of annual mean maximum temperature at $95 \%$ significance level. Maximum temperature has increased $0.15{ }^{\circ} \mathrm{C}$ from 2 nd to 3 rd decade and $0.16{ }^{\circ} \mathrm{C}$ from 4 th to 5 th. As IPCC fourth assessment report mentioned the increasing trend of temperature (Detail has discussed in literature review). There also exists seasonal variation of maximum temperature. Like, in winter maximum temperature is showing decreasing trend and has fallen $0.82{ }^{\circ} \mathrm{C}$ from 1 st to 5 th decade, and the trend continue till pre-monsoon but little flatter then winter trend. Monsoon has a significant increasing trend of maximum temperature. From third decade to forth decade it had increased $1.01{ }^{\circ} \mathrm{C}$, which is the highest value of 50 years trend. Post-monsoon also shows increasing trend on temperature (Figs. 3, 4, 5, 6).

\section{Trend of annual average minimum temperature}

Like the annual mean maximum temperature, the trend of annual mean minimum temperature also showing an

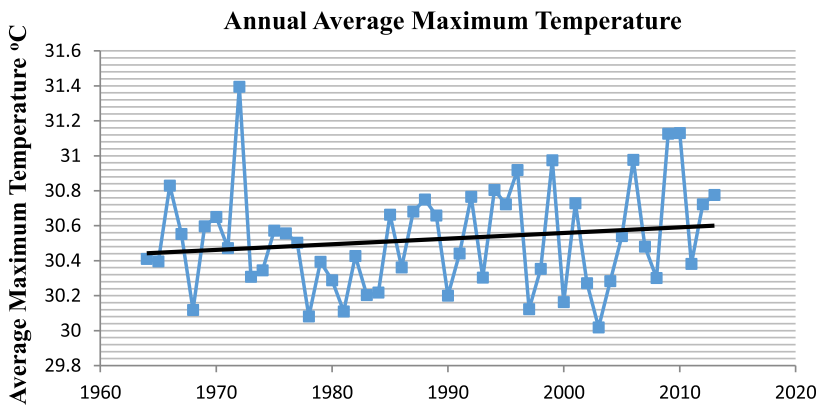

Fig. 2 Trend of annual average maximum temperature

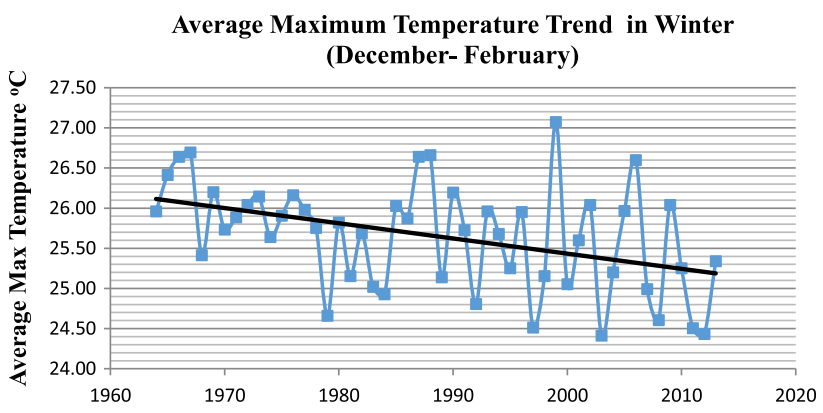

Fig. 3 Trend of annual average maximum temperature in winter 


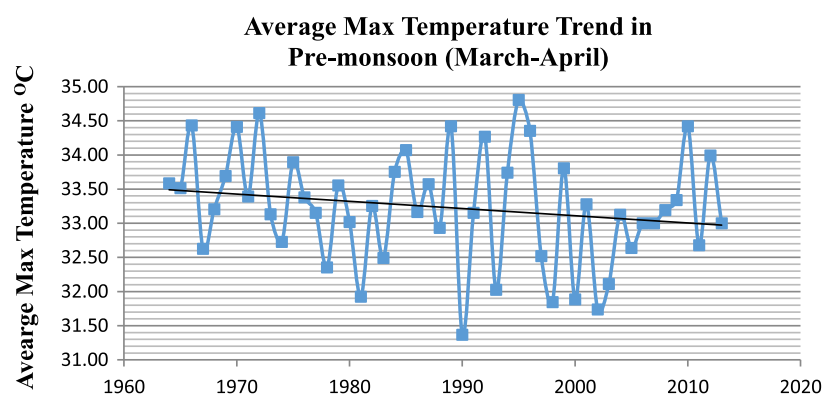

Fig. 4 Trend of annual average maximum temperature in premonsoon

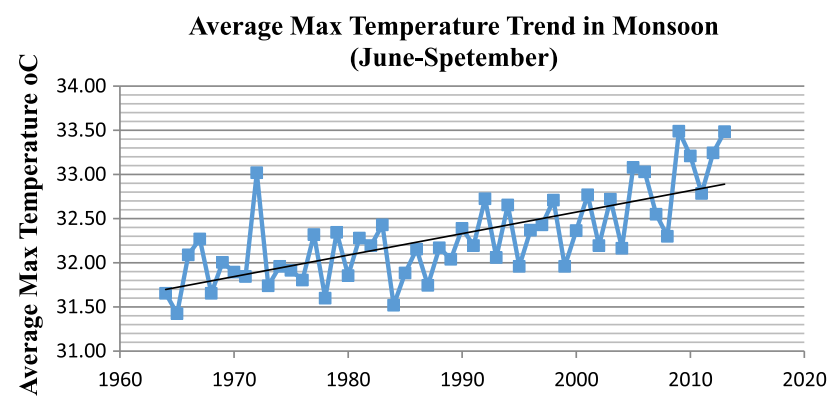

Fig. 5 Trend of annual average maximum temperature in monsoon

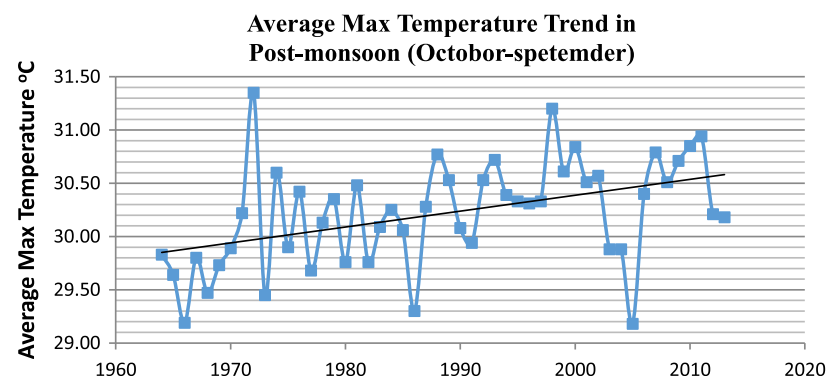

Fig. 6 Trend of annual average maximum temperature in postmonsoon

increasing trend (Fig. 7) and which is $1.3{ }^{\circ} \mathrm{C}$ per century. The result of this study corroborated the results of IPCC (2001) report and findings of Ahmed (2006). In pre-monsoon and monsoon mean minimum temperature has increased more than other two seasons. In winter the minimum temperature has increased $0.19^{\circ} \mathrm{C}$ within 1 st to 2nd decade, $0.26{ }^{\circ} \mathrm{C}$ within 3 rd to 4 th decade and $0.15{ }^{\circ} \mathrm{C}$ up to 5 th decade, so within recent last decade means min temperature has decreased. In pre-monsoon the mean minimum temperature has increased $0.86{ }^{\circ} \mathrm{C}$ till 5 th decade and in monsoon the mean minimum temperature has increased $0.35{ }^{\circ} \mathrm{C}$ within the same time period. In postmonsoon the mean minimum temperature has increased $0.2{ }^{\circ} \mathrm{C}$ from 1 st to 5 th decade (Figs. 8, 9, 10, 11).

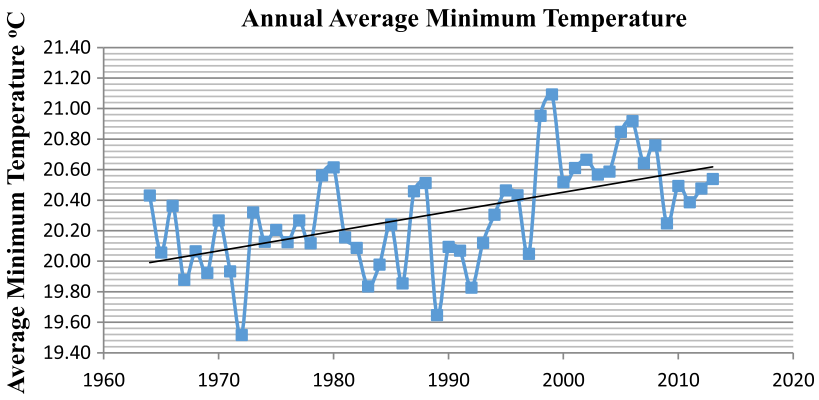

Fig. 7 Trend of annual average minimum temperature

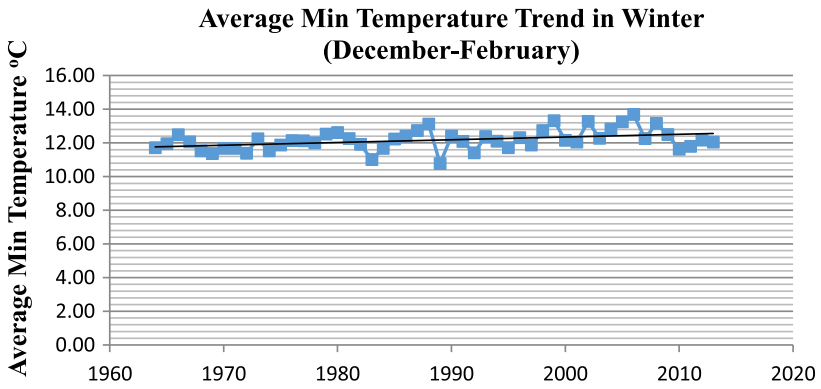

Fig. 8 Trend of annual average minimum temperature in winter

\section{Trend of annual average temperature}

The time series shows increasing trend of mean annual temperature (Fig. 12). Considering the decadal analysis, mean annual temperature has decreased $0.45{ }^{\circ} \mathrm{C}$ from 1 st decade to 2nd decade, and increased $0.25{ }^{\circ} \mathrm{C}$ from 3 rd decade to 4 th decade. From 4 th decade to 5 th decade it has increased $0.094{ }^{\circ} \mathrm{C}$.

\section{Analysis of annual average rainfall}

\section{Trend of annual average rainfall}

The mean annual rainfall shows quite static trend (Fig. 13), where the significant declining begins from the recent last two decades. IPCC fourth assessment report, also mentioned the declining trend of rainfall in Bangladesh (IPCC 2007).

In winter and monsoon season rainfall shows decreasing trend, in pre-monsoon trend is quite static in nature but in post monsoon rainfall is showing very little increasing trend. Whatever the 50 years rainfall trend shows, rainfall is decreasing considerably in the last recent decade in all the season. (Figs 14, 15, 16, 17). Considering annual change in rainfall pattern in percentage pronounces that, since 1964 there was increasing as well as decreasing amount of mean rainfall but in recent last decade percentage of rainfall in quantity is decreasing than increasing in quantity (Fig. 18). 


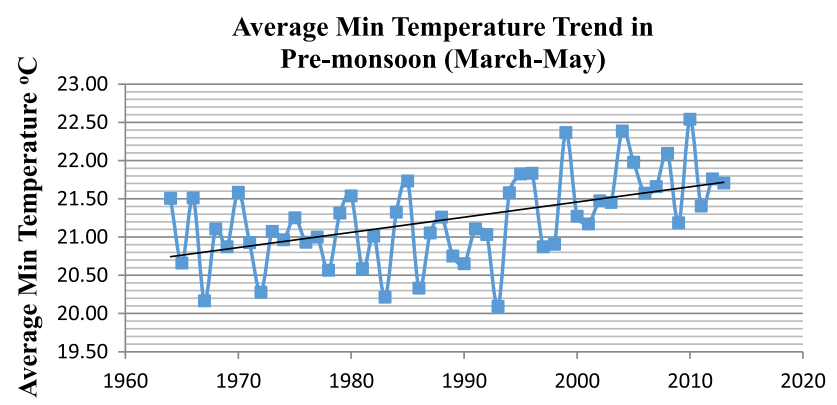

Fig. 9 Trend of annual average minimum temperature in premonsoon

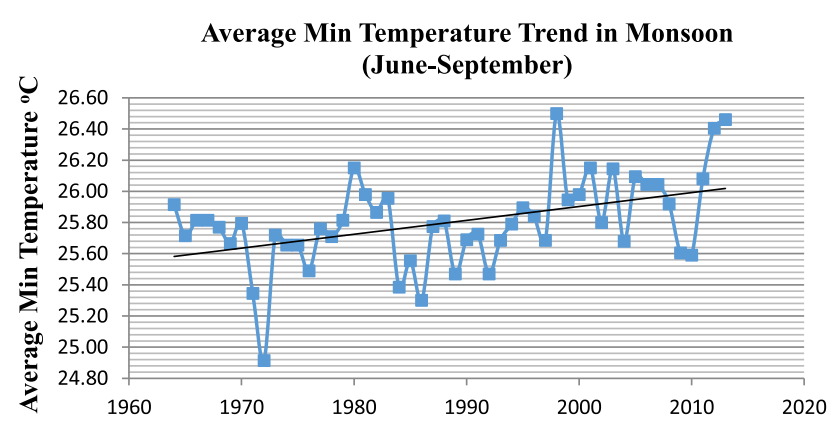

Fig. 10 Trend of annual average minimum temperature in monsoon

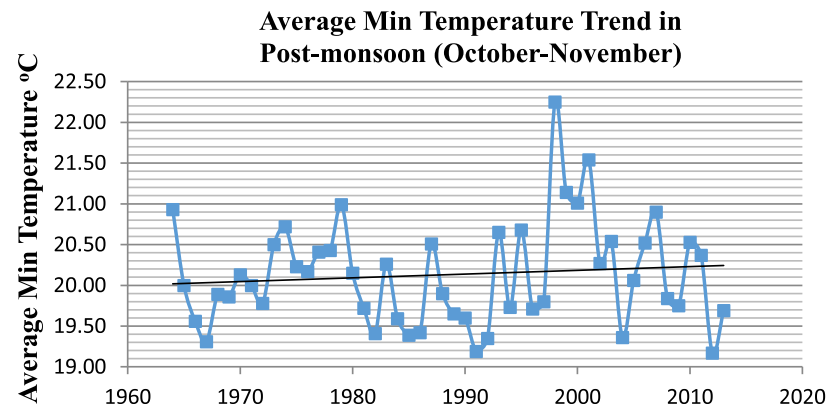

Fig. 11 Trend of annual average minimum temperature in postmonsoon

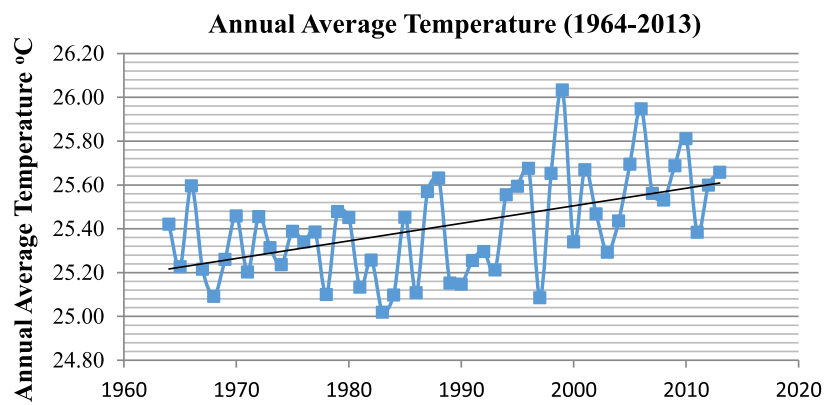

Fig. 12 Trend of annual average temperature

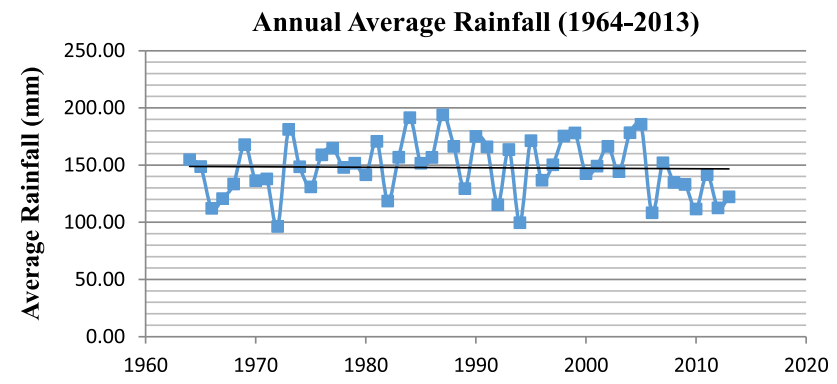

Fig. 13 Trend of annual average rainfall

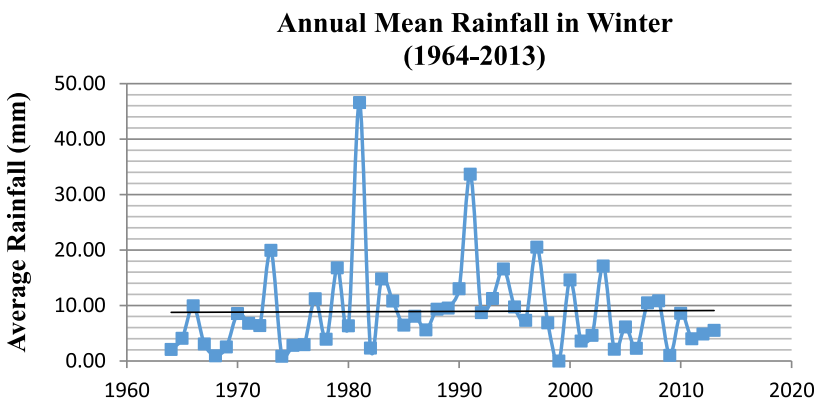

Fig. 14 Trend of annual average rainfall in winter

\section{Analysis of annual average relative humidity (percent)}

\section{Trend of annual average relative humidity (percent)}

Fifty years of relative humidity shows significant increasing trend. Till 1990s relative humidity was below $78 \%$ and till 1980s the incremental rate of relative humidity was $2.32 \%$ but after that time within 2000 the incremental rate was $2.9 \%$, and from that 2000 to 2013 the incremental rate slowed down and became $2.2 \%$ (Fig. 19). Means that from 2nd to 4th decade there was a significant increasing trend, after that in the recent last decade it shows little decreasing trend which is $0.06 \%$.

\section{Inter-action of climatic indicators in north-western region}

Spatial distribution of changing pattern of climatic indicators of northwestern region and their interaction shows exactly the hypothetical interaction of climatic indicators (Figs. 20, 21, 22, 23). Southern part (Rajshahi, Natore, Pabna, Nawabganj, Sirajgonj, Borga) of northwestern region shows increasing trend of annual mean maximum and annual mean minimum temperature. As a result atmosphere of this area 


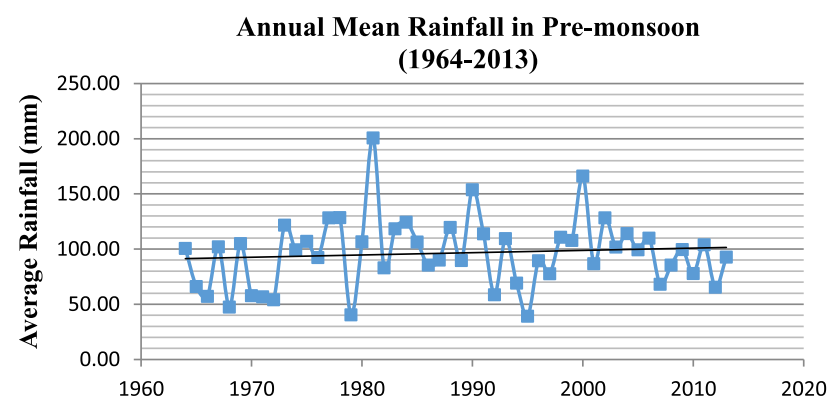

Fig. 15 Trend of annual average rainfall in pre-monsoon

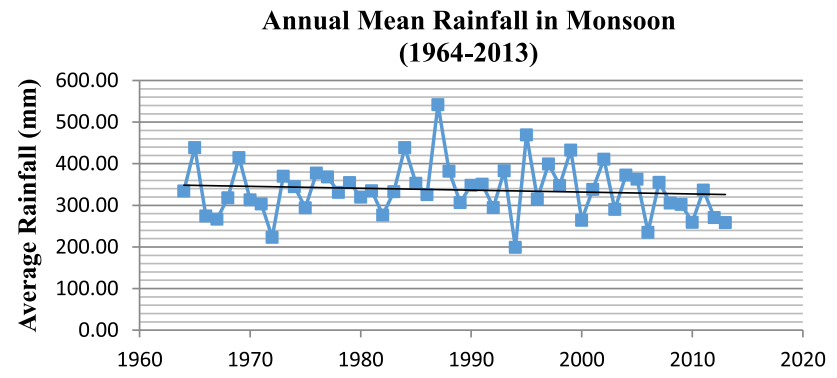

Fig. 16 Trend of annual average rainfall in monsoon

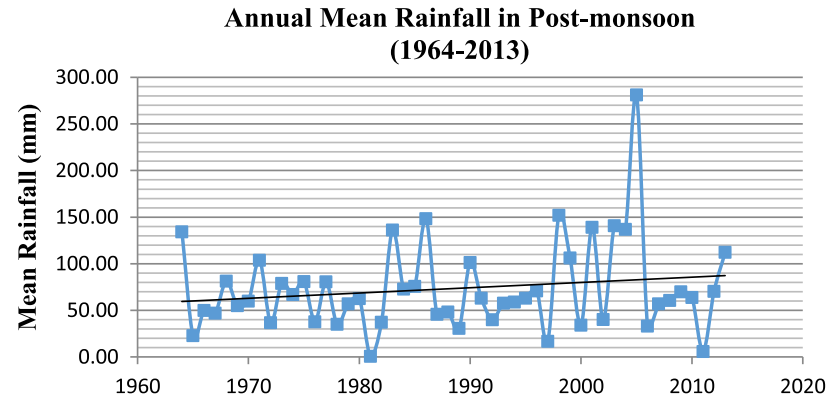

Fig. 17 Trend of annual average rainfall in post-monsoon

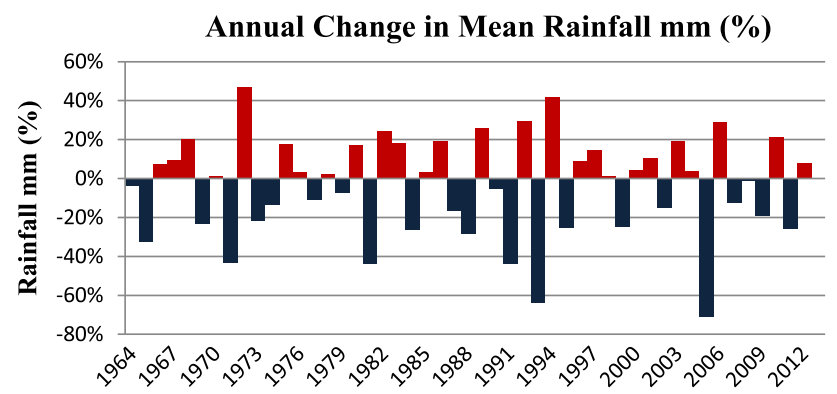

Fig. 18 Pattern of annual average rainfall change in percent (1964-2013)

can hold less water bubble, which means low percentage of relative humidity and rainfall. Where as in northern part of this region (Panchagarh, Thakurgaon, Nilphamari, Kurigram, Dianjpur and Rangpur) has less increasing trend of

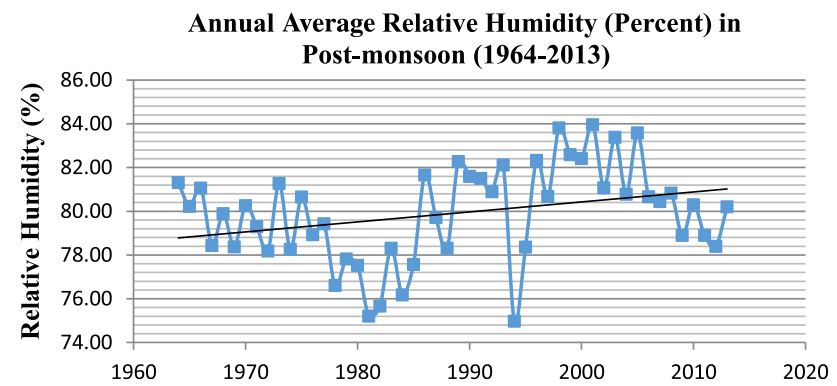

Fig. 19 Trend of annual average relative humidity (percent)

maximum and minimum temperature. So, atmosphere of this part has comparatively more water holding capacity so relative humidity is much higher here. Northern part shows high annual mean rainfall.

\section{Temporal analysis of ground water table depth}

For analyzing ground water table depth of north-western region five upazila from five district has been selected and from each upazila a well has been selected.

There is no river runs through Dinajpur district and the geographical scenario is similar in whole district so rainfall is the only source of revitalization. Figure 24 explains significant increasing trend of water table depth over the time. Till 1990 there was very little change of water table depth but since 1995 the depth begins increasing. In monsoon, average rainfall is decreasing and average ground water table penetration is increasing which mean in monsoon season revitalization rate is getting lower (Fig. 25). In 1995 rainfall was increased but ground water table depth has also increased instead of decreasing (if we consider general logic) and same phenomenon has occurred in 2005.

Sujanagar upazila of Pabna district is situated beside Karatoa-Atrai River so it is expected that the increment rate of water table depth would be less. Figure 26 shows increasing trend of water level but the increasing rate is low compare to Dinajpur district. This might be the cause of availability of nearby surface water source. In monsoon season, since 1981-2001 water table depth was quite similar but considering the interaction of rainfall and ground water table depth, in 2011 rainfall was increased to $362 \mathrm{~mm}$ but ground water level was decreased up to $3.87 \mathrm{~m}$ which is the highest in terms of depth (Fig. 27)

Godagari Upazila of Rajshahi district is situated beside Padma River which acts as a surface water source for revitalizing ground water aquifer. Figure 28 shows increasing trend of ground water depth. Compare to Dinajpur and Pabna district water depth is high in Rajshahi district. From 1981 to 2001 depth was near around $10 \mathrm{~m}$ 


\section{Spatial Distribution of Mean Maximum Temperature}

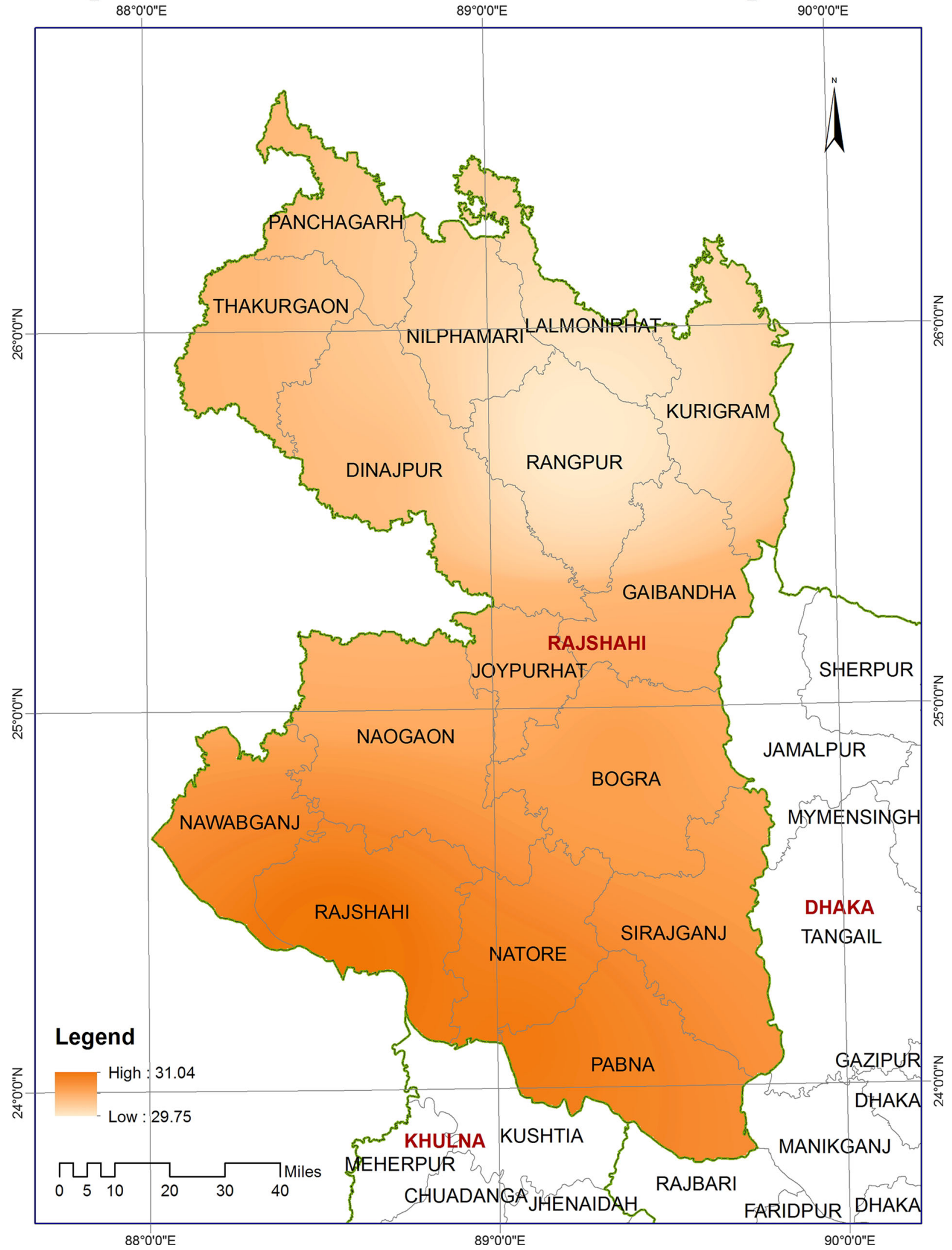

Fig. 20 Spatial variation of mean maximum temperature 


\section{Spatial Distribution of Mean Minimum Temperature}

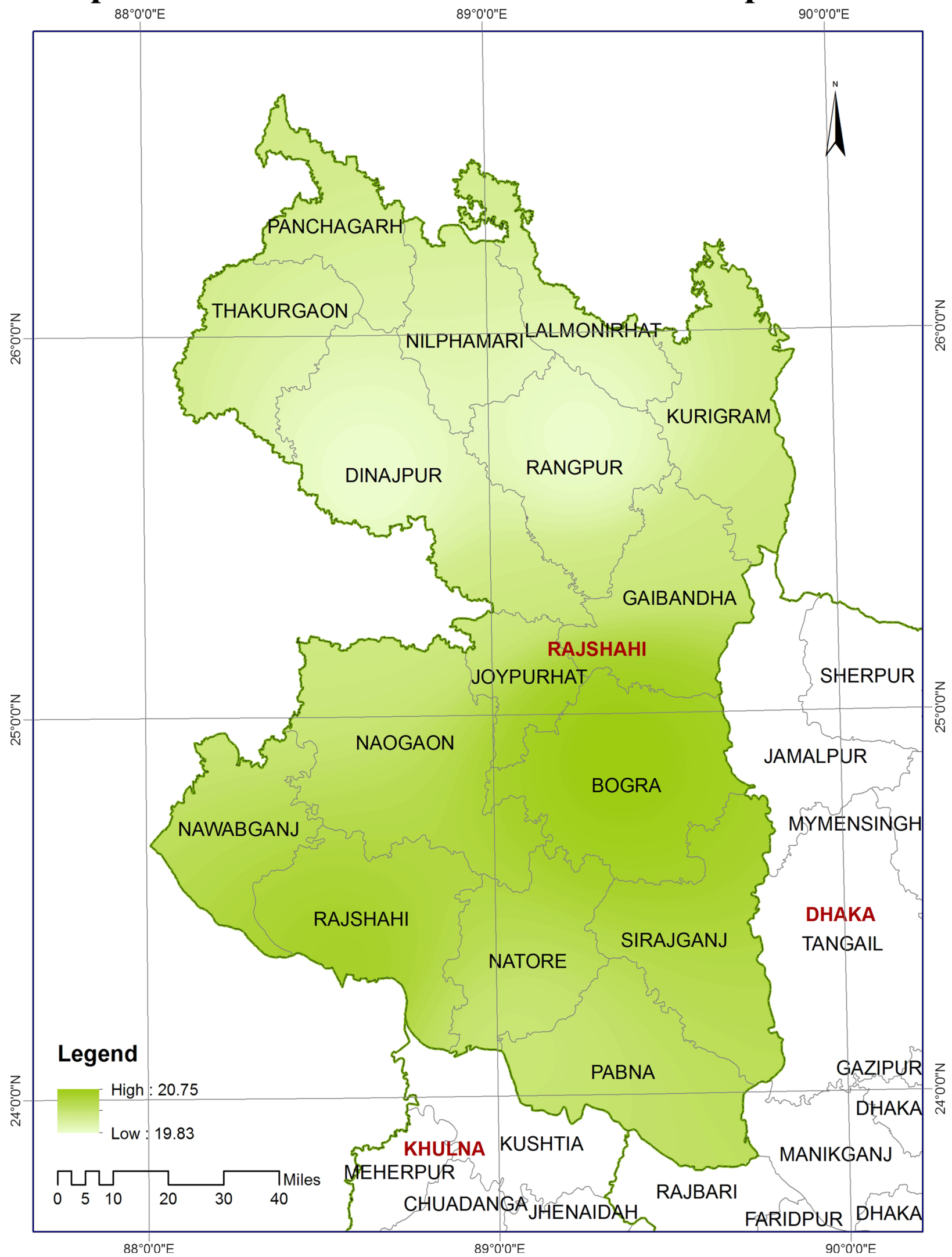

Fig. 21 Spatial variation of mean minimum temperature 


\section{Spatial Distribution of Mean Rainfall}

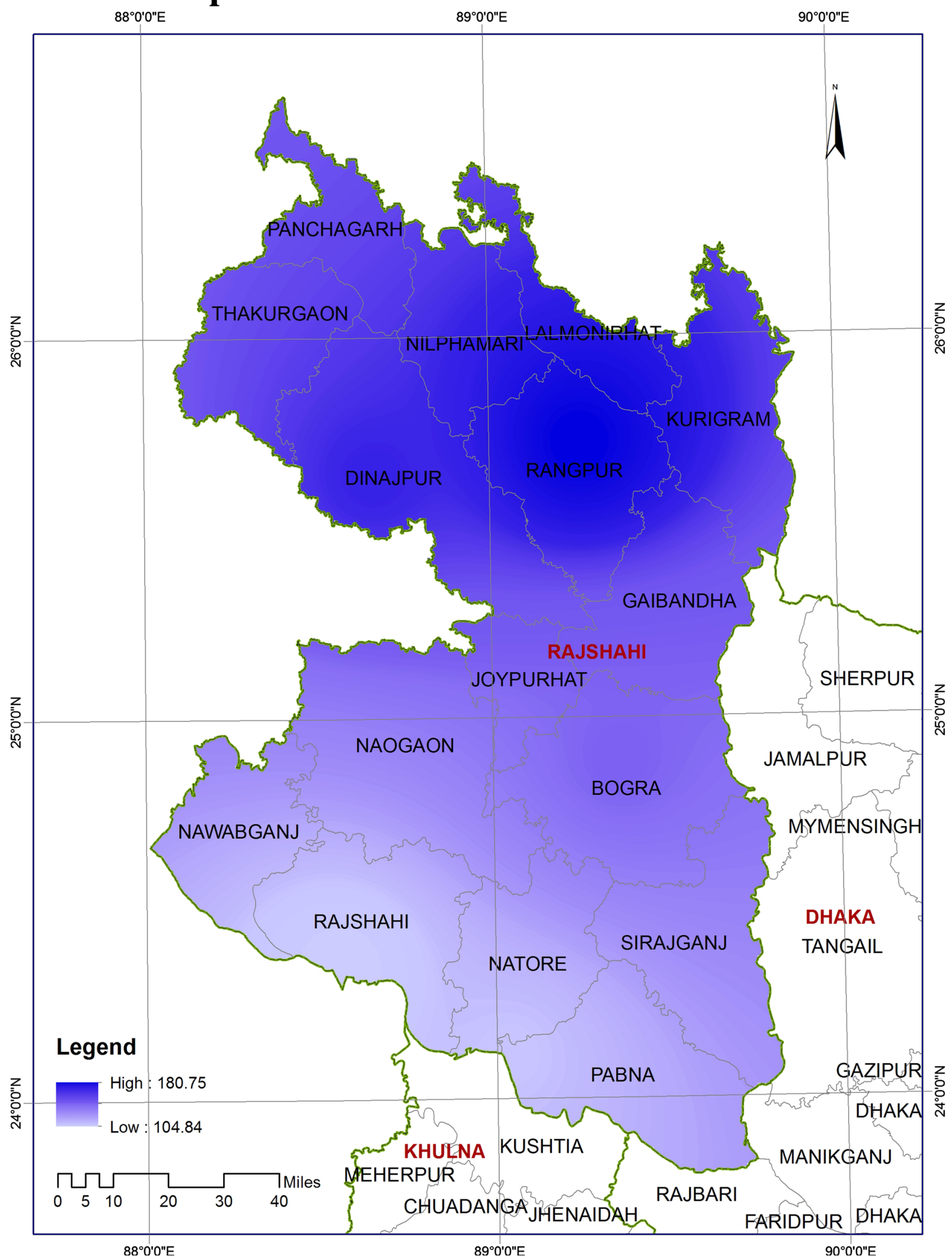

Fig. 22 Spatial variation of mean rainfall 


\section{Spatial Distribution of Mean Relative Humidity}

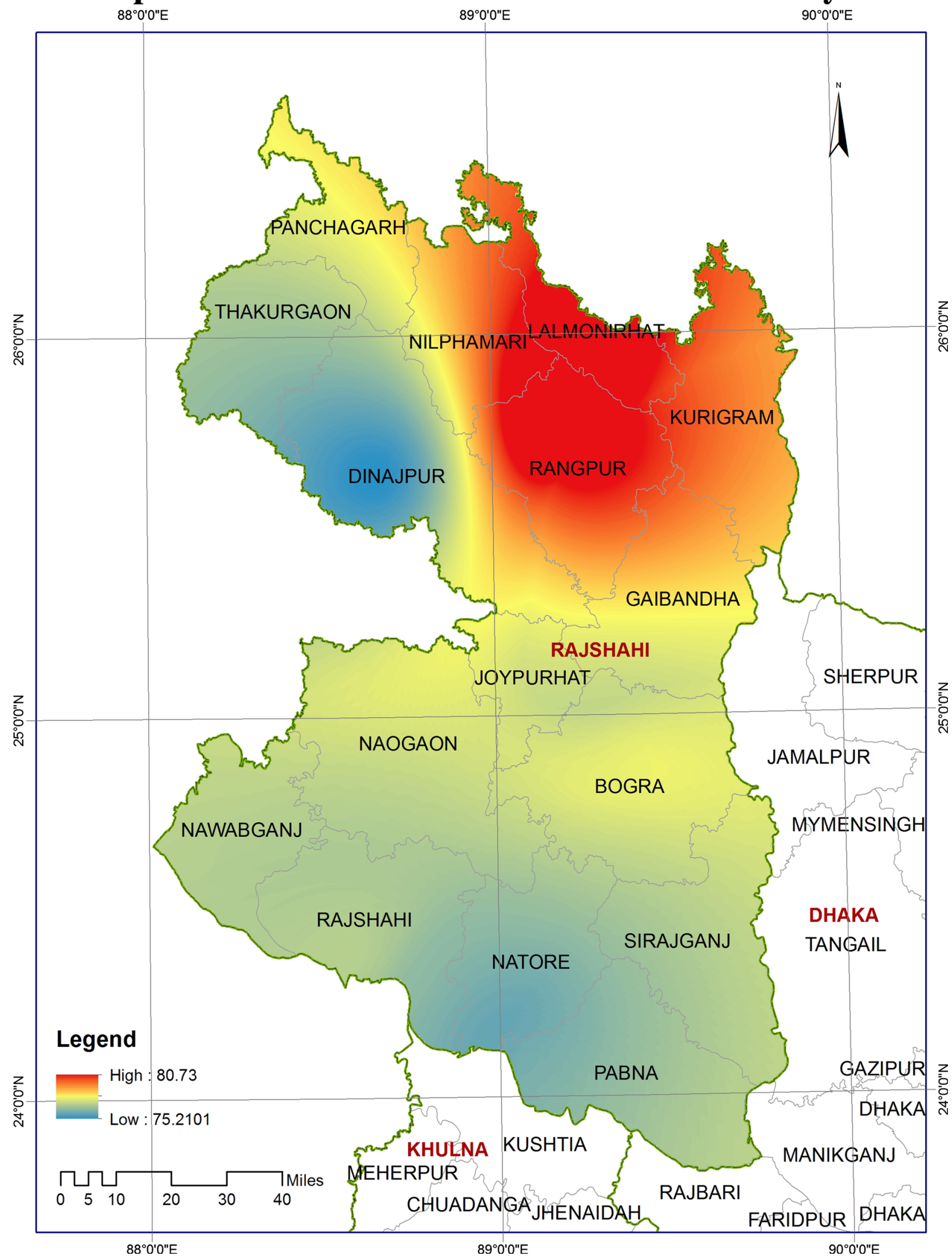

Fig. 23 Spatial variation of mean relative humidity 
GW Table Depth of Hakimpur Upazila (Well Id.- GT2747021)

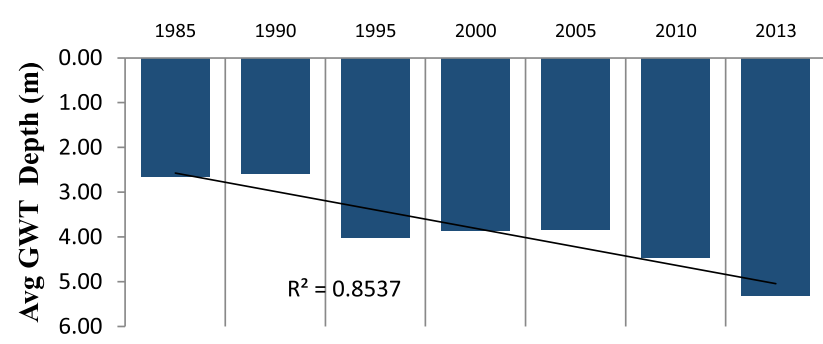

Fig. 24 Trend of GW table depth of Hakimpur Upazila, Dinajpur

\section{Annual Average Rainfall Vs. GW Revitalization}

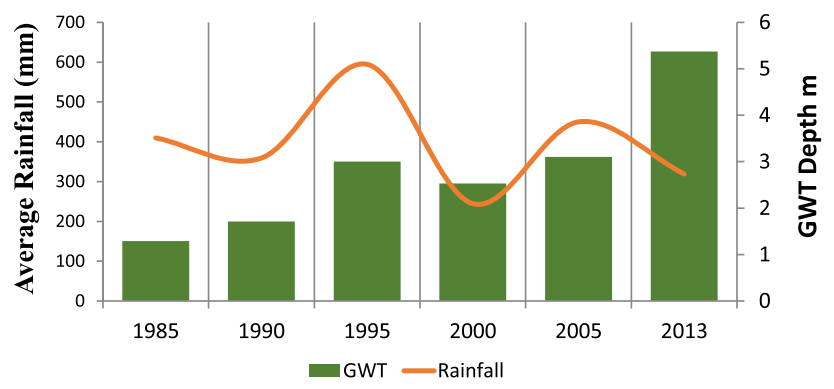

Fig. 25 Comparison of annual average rainfall and GW level revitalization rate

\section{GW Table Depth of Sujanagar Upazila} (Well Id.-GT7683034)

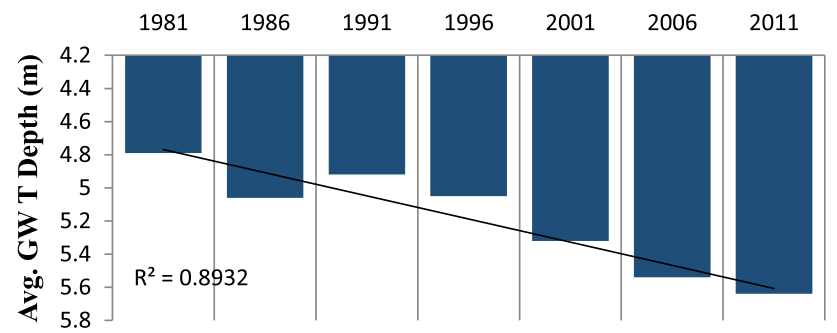

Fig. 26 Trend of GW table depth of Sujanagar Upazila, Pabna

and by 2011 depth reached at $17.34 \mathrm{~m}$. Form 2001 in monsoon ground water depth has increased very rapidly. In 2011 rainfall was increased comparing from 1986-2006 but ground water level has decreased. This scenario denotes that influence of surface water source and rainfall for revitalization is getting lower in recent decades (Fig. 29).

Badarganj Upazila of Rangpur district is situated far form surface water source and depth trend is showing increasing trend. But in 1996 and 2011 there was rising trend of water table (Fig. 30) because rainfall was increased in those particular year. Figure 31 shows the trend of ground water depth in monsoon of last three
Annual Average Rainfall Vs. GW Revitalization

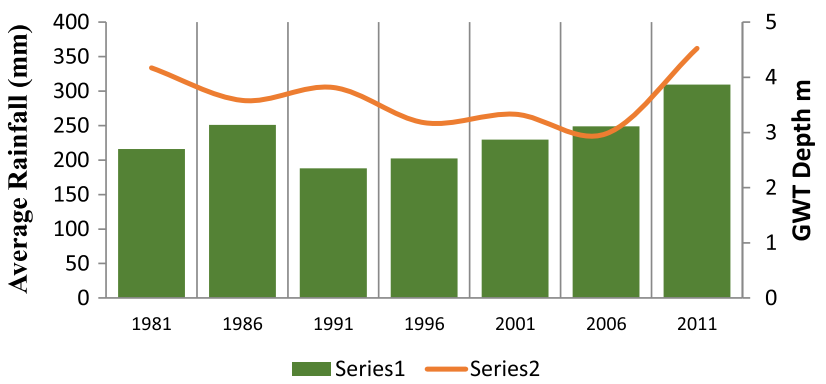

Fig. 27 Comparison of annual average rainfall and GW level revitalization rate

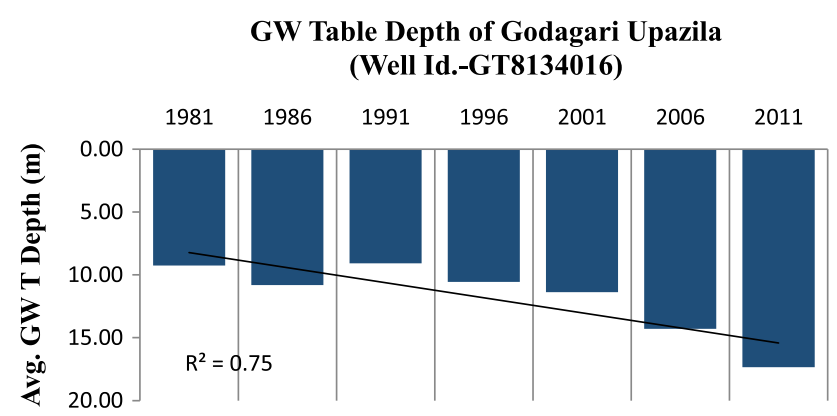

Fig. 28 Trend of GW table depth of Mohanpur Upazila, Rajshahi

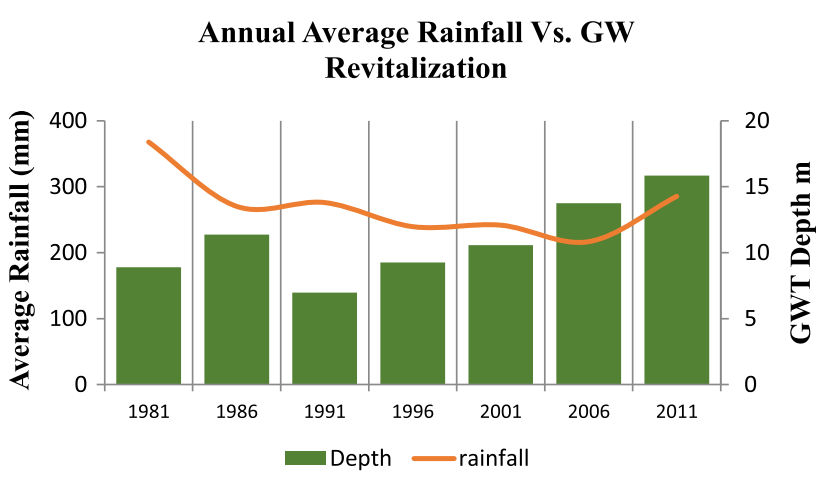

Fig. 29 Comparison of annual average rainfall and GW level revitalization rate

decades where rainfall is decreasing and water table depth is increasing.

Ground water depth in Adamdighi Upazila of Bogra district showing continuous increasing trend of ground water depth since 1991 (Fig. 32). Within the time period of 2001 average rainfall was at highest rate, $377.75 \mathrm{~mm}$ and in 2006 average rainfall rate was lower, $226.5 \mathrm{~mm}$. Though there was increased rainfall in 2001 and in 2011 but ground water depth was increased more than 1.5 and $2.1 \mathrm{~m}$ respectively (Fig. 33). 


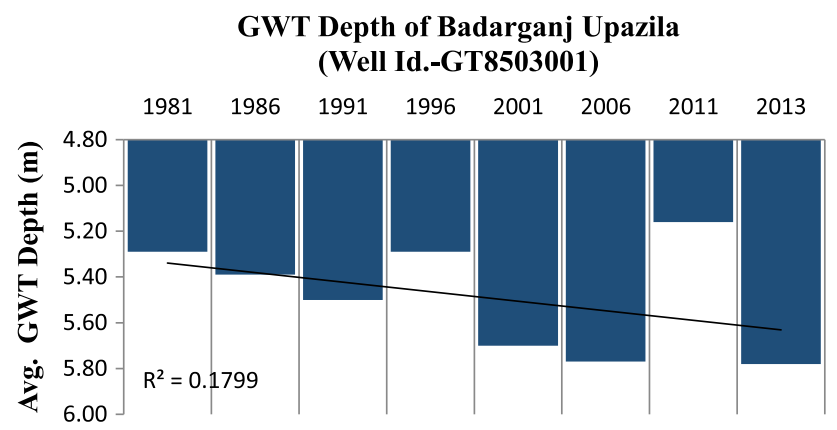

Fig. 30 Trend of GW table depth of Gangachara Upazila, Rangpur

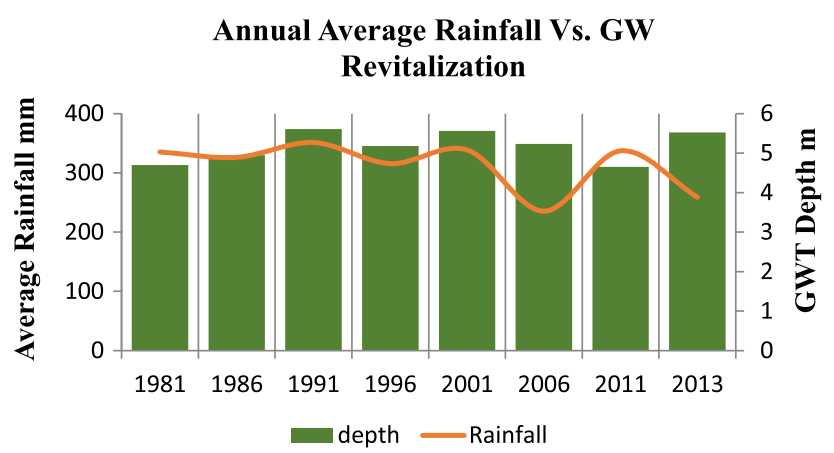

Fig. 31 Comparison of annual average rainfall and GW level revitalization rate

\section{GWT Depth of Adamdighi Upazila} (Well Id.- GT1006001)

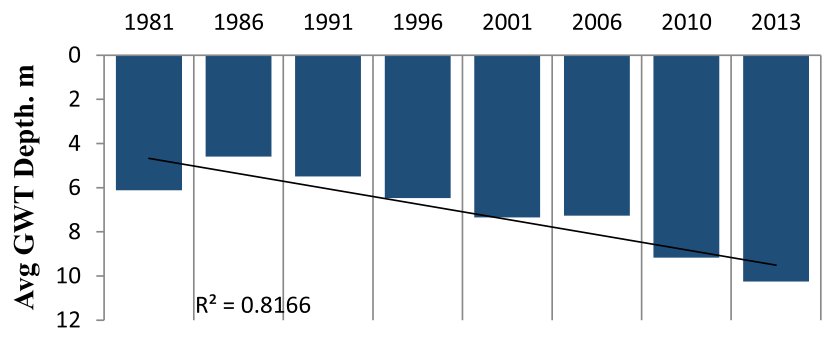

Fig. 32 Trend of GW table depth of Adamdighi Upazila, Bogra

\section{Spatial analysis of ground water level (variography and semivariogram model)}

Spatial distribution of GW level of Dinajpur district shows (Fig. 34) that, depletion rate is high in south part of this region, consists of Phulbari, Nawabganj, Hakimpur, Ghoraghat and Birampur Upazila. Average depletion rate is $4.2 \mathrm{~m}$. Some part of north western side of the region shows rising of water level, noted that in north western part there exists natural surface water source.

In Pabna District Spatial analysis demonstrates (Fig. 35) that, average maximum depletion level is $6.37 \mathrm{~m}$ in
Annual Average Rainfall Vs. GW Revitalization

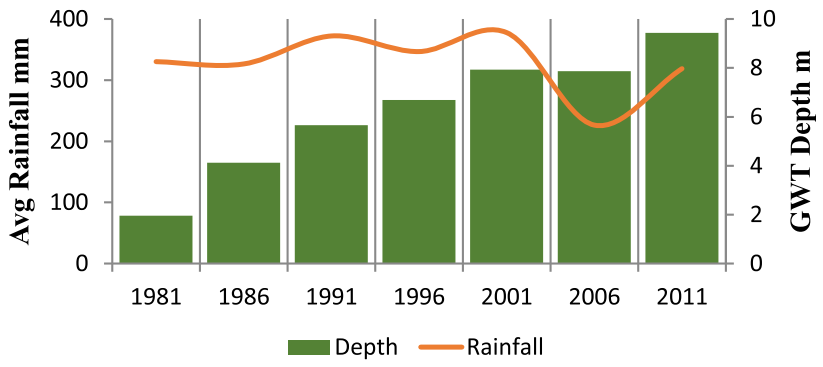

Fig. 33 Comparison of annual average rainfall and GW level revitalization rate

northern part. In Chatmohor, Bhangura, Faridpur and Atghoria upazila depletion rate is high, within the upazila of Bera and Sujanagar shows rising of water table. This is also to be noted that both the upazila are situated beside Jamuna River which might be the prime cause of rising or high revitalization rate of ground water table. The average maximum rising value is $1.9 \mathrm{~m}$. Parts of Iswardi and Pabna Upazila also showing rising trend of water table and which are situated beside the river.

Spatial analysis of water table depth in Rajshahi district describes (Fig. 36), in Tanor and Mohonpura upazila depletion rate is high, where the average highest depleted water table height is $10.89 \mathrm{~m}$. Another scenario is, in Charghat, Bagha and Godagari upazila shows slightly rising trend of water level. These upazila's are situated near the Padma River. While Puthia, Paba Durgapur upazila show slightly decreasing trend of ground water level.

Within Rangpur district in Badarganj upazila depletion rate is high (Fig. 37). Average maximum depletion height was $3.4 \mathrm{~m}$. Some part of Mithapur, Kaunia and Pirganj upazila also show high depletion rate. Gangachara and a part of Rangpur show the rising tendency in water table height, where a naturel water body passes through this upazilas.

And within Bogra District (Fig. 38) in Shariakandi, Gabtali, Dhunat and Sibganj upazila revitalization rate is high. The maximum rising height of these upazila is $2.13 \mathrm{~m}$. These upazilas are also situated nearby natural water source. Whereas Adamdighi, Dubchachia, Kahalu, Nandigram and Sherpur shows high depletion trend and average depletion is level was $6.36 \mathrm{~m}$.

So considering the spatial analysis this can be concluded that rainfall has less significant role of revitalization this might be cause of thickness of clay in this region whereas surface water source has a significant role on ground water revitalization and this is the scientific inter-action between surface water and ground water source. 

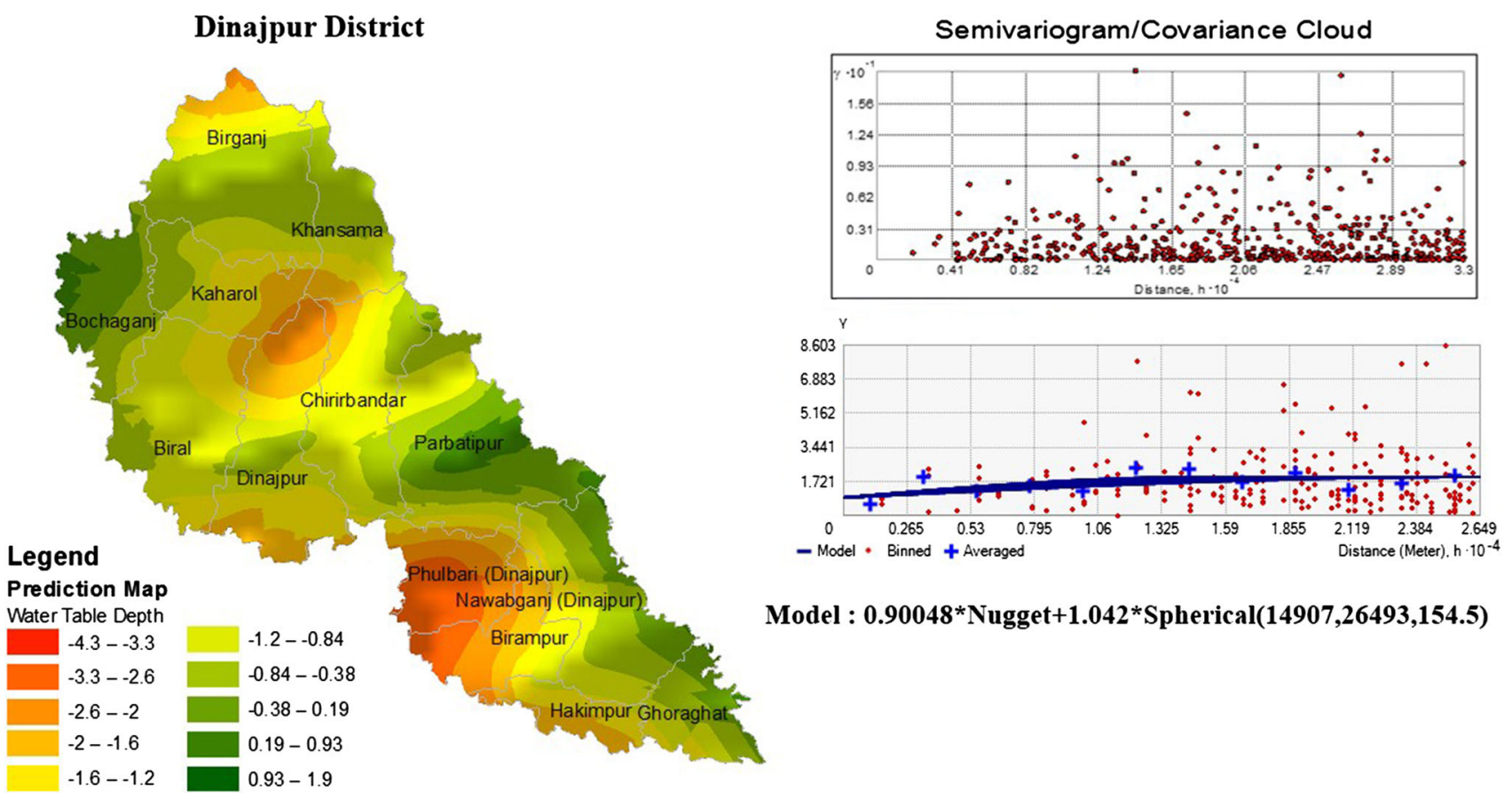

Model : $0.90048 *$ Nugget $+1.042 *$ Spherical $(14907,26493,154.5)$

Fig. 34 Spatial changes of ground water level of Dinajpur District
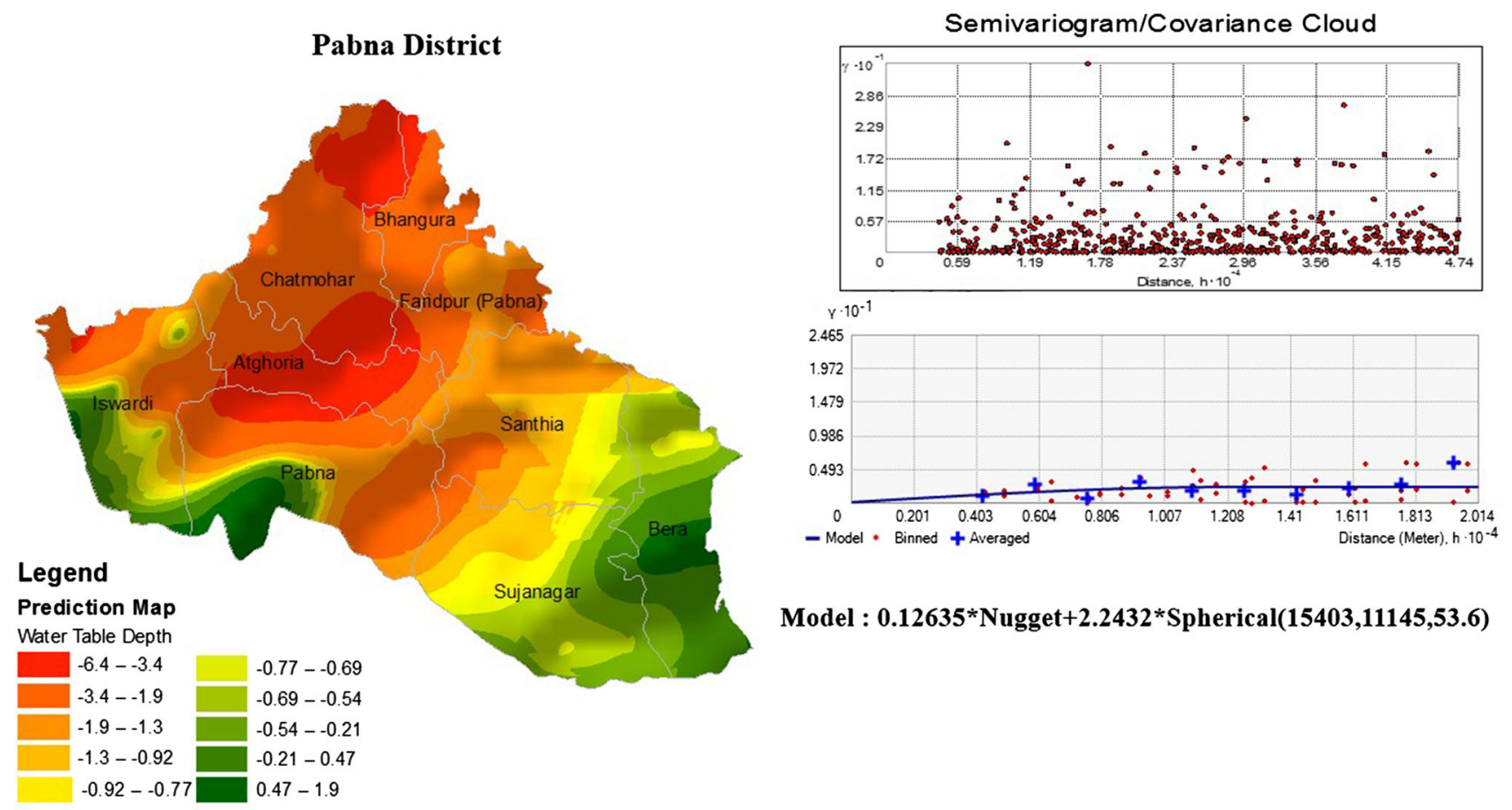

Fig. 35 Spatial changes of ground water level of Pabna District

\section{Trend of surface water level}

Figure 39 shows time series of box and whisker plots of surface water level in Dinajpur district. Except 1985 and 2006 all the boxes are showing negative

skewedness, means average water level is much less considering its maximum and minimum flow level over the year and from 2003 upper whiskers means maximum water flow level are also declining. In 2003 and 2011 rainfall was increased compared to previous time 


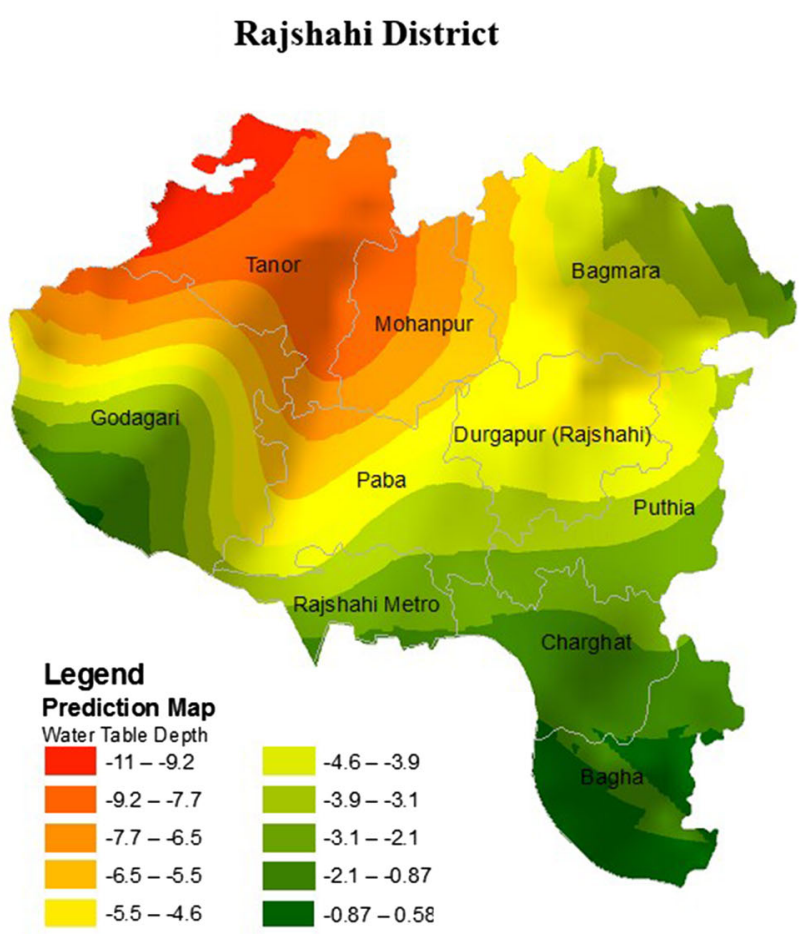

Fig. 36 Spatial changes of ground water level of Rajshahi District

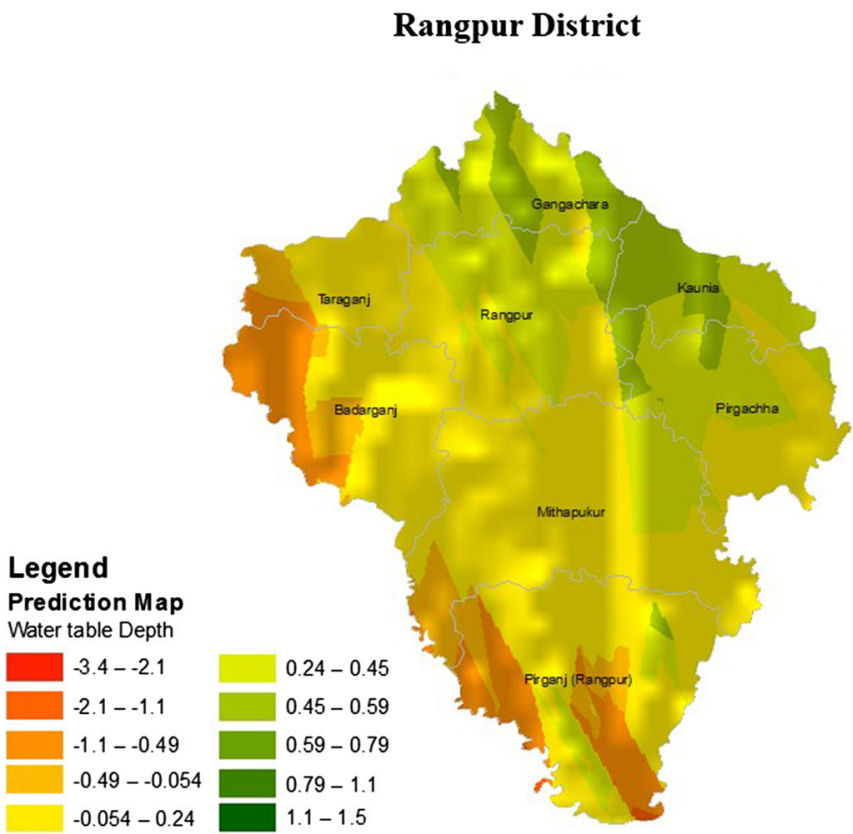

Fig. 37 Spatial changes of ground water level of Rangpur District

but surface water level both max and min flow level has decreased.

In Pabna district boxes and whiskers (Fig. 40) are showing high fluctuation of surface water level over the year. From 1996 average flow level was in median value level considering max min flow level of each year. But

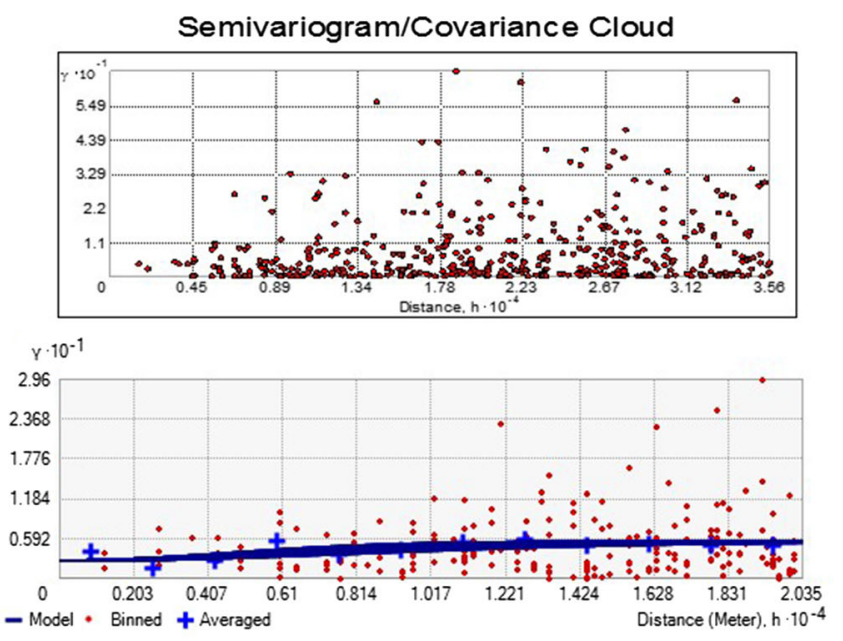

Model : $2.5084 *$ Nugget $+3.1653 *$ Stable $(15435,11689,38.5,2)$

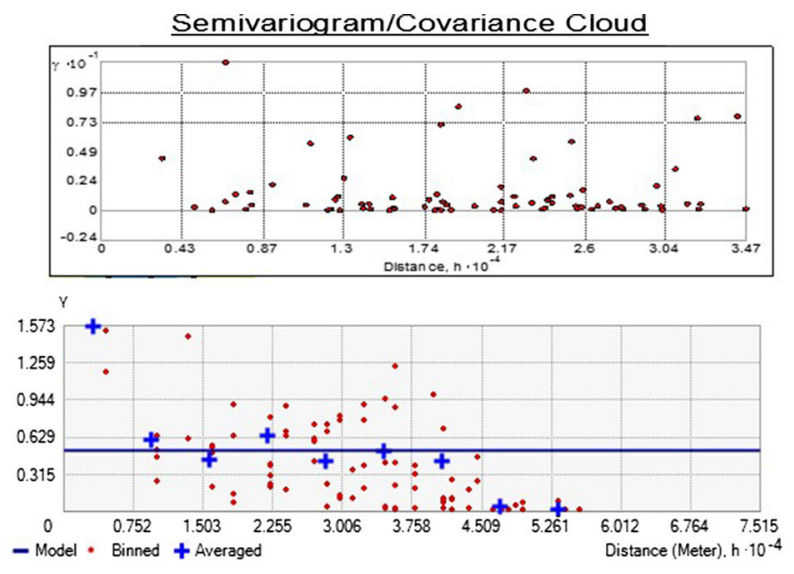

Model : $1.2315 *$ Nugget $+0 *$ Stable $(63151,63151,0.0,0.2)$

form 2001 maximum as well as minimum flow level is decreasing, form the same year quantity of rainfall has also decreased. So it can be said that decaling trend of rainfall and surface water level are significantly correlated.

In Rajshahi district from 1981 to 2006 all the boxes are showing negative skewedness in nature. Till 1996 there 

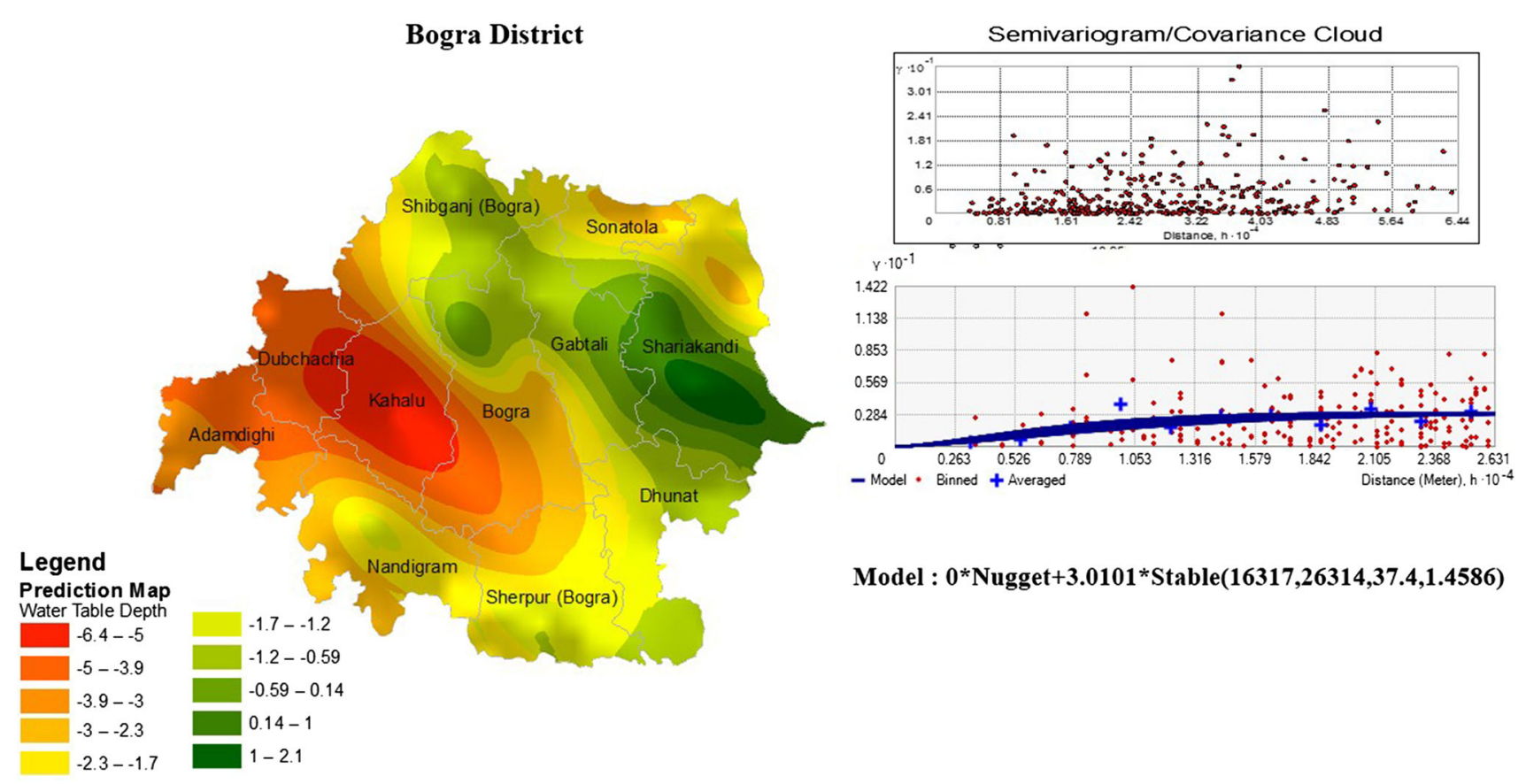

Model : 0 *Nugget $+3.0101 *$ Stable(16317,26314,37.4,1.4586)

Fig. 38 Spatial changes of ground water level of Bogra District

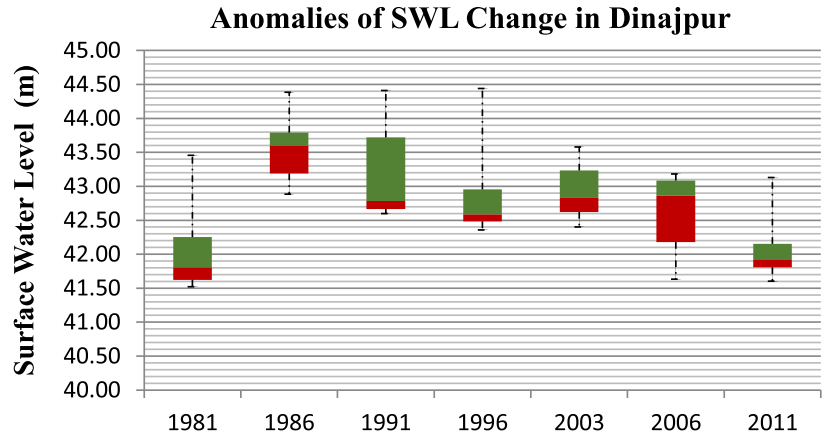

Fig. 39 Temporal analysis of surface water level of Dinajur District

was an increasing trend of min water level and from 2001, min as well as max water level is showing decreasing trend (Fig. 41). Rainfall of this district is also dwindling day by day.

Till 1991 surface water level in Rangpur district is showing negative skewedness with quite similar minimum and maximum flow level. But from 1996 maximum and minimum water level is showing decreasing trend (Fig. 42).

In Bogra district surface water level both maximum and minimum are showing quite similar trend along with negative skewedness and also the fluctuation rate was less. But in 2006 maximum water level is showing much minimum value comparing previous years and in 2006 rainfall rate was also less (Fig. 43).

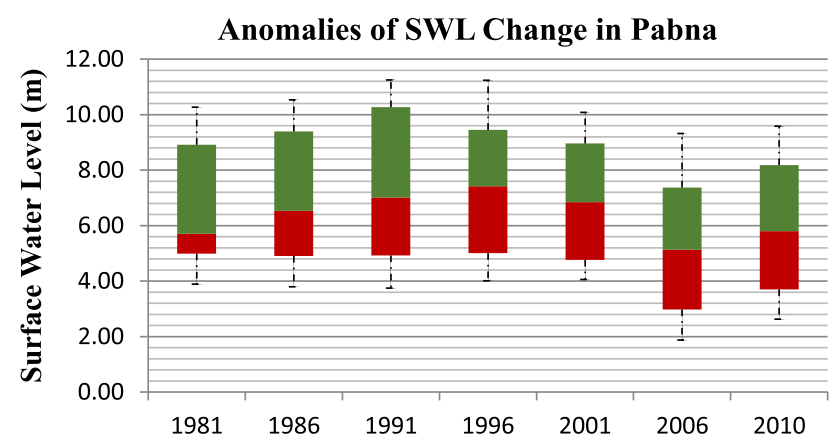

Fig. 40 Temporal analysis of surface water level of Pabna District

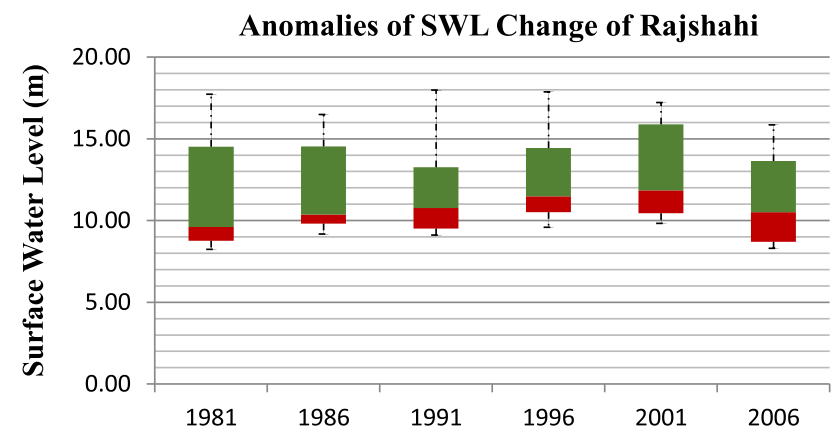

Fig. 41 Temporal analysis of surface water level of Rajshahi District

So it can be concluded from box and whisker plot analysis that, quantity of rainfall has significant influence on maximum and minimum water level; recent decade 


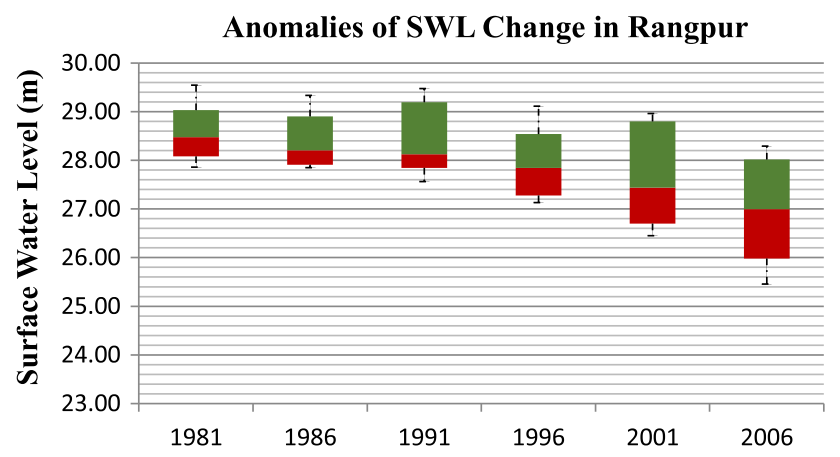

Fig. 42 Temporal analysis of surface water level of Rangpur District

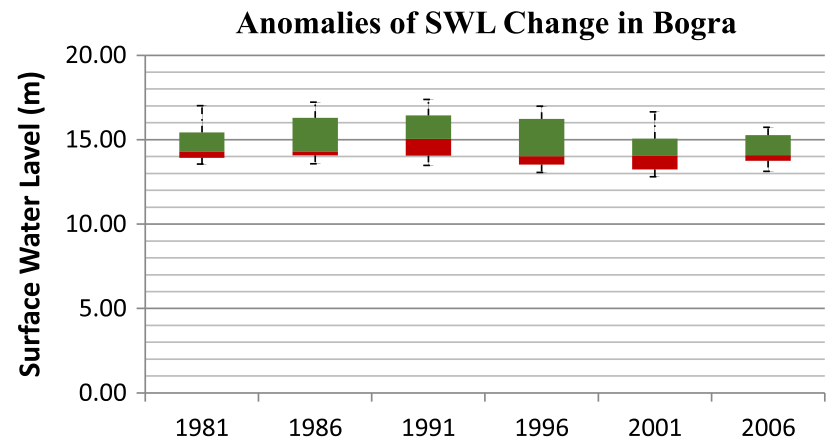

Fig. 43 Temporal analysis of surface water level of Bogra District

average surface water flow level is declining; in recent decade most of the districts, range of boxes are getting less which indicates water holding capacity of sources are declining.

\section{Major findings}

Maximum temperature and minimum temperature both are showing increasing trend. But maximum temperature is increasing more rapidly than the minimum temperature.

In winter season maximum temperature is decreasing but minimum temperature is almost static, it has been noted that from 2005 minimum temperature is decreasing more hastily.

Annual mean rainfall shows very little decreasing trend in northwestern region. It is showing decreasing amount of rainfall from 2005.

The 50 years trend of relative humidity shows significant increasing trend, but from 2000 relative humidity is decreasing. This is mainly because of increasing temperature of both maximum and minimum temperature. This makes the gas holding capacity of the atmosphere more than the holding capacity of tiny water bubble. So the atmosphere is becoming drier progressively.
In monsoon Relative Humidity is significantly decreasing, especially after 2000 .

Water table of the entire selected wells are showing decreasing trend in north western region. Among them the ground water depletion rate is higher in Pabna, Bogra and Rajshahi districts.

In monsoon ground water revitalization rate is insufficient. All the districts (except Rangpur) show depletion of water table in all the 4 months of monsoon.

Due to increased temperature evapotranspiration might be increased; it might be another cause to reduced water availability from ground water sources in drought prone areas.

It can be said that rainfall alone is not sufficient to revitalize ground water.

Surface water level is showing decreasing trend in all the districts. Where as in recent decade, $75 \%$ time of a year, surface water flows are below its median level.

Surface water source has significant influence on ground water revitalization and recharge. Spatial analysis shows that presences of river/canals have significant impact on the ground water depletion/revitalization rate.

The spatiotemporal distribution and intensity of rainfall as well as change of surface water level and runoff directly and significantly impacted on the dynamics of ground water.

\section{Possible economic impacts of drought in the north- western districts of Bangladesh}

Increasing trend of maximum temperature may turn a cultivable land into a barren field. So being a droughtprone region, this part of Bangladesh bears the possibility of losing much of its land asset due to climate change induced increasing temperature.

Drought degrades fertility and moisture contents of soil. This leads to the use of additional fertilizer and irrigation to maintain soil quality for cultivation. As a result, input costs are also expected to increase. (BBS (2010) reported on the cost of production of Aman crop (2008-2009) against the loss of soil fertility and moisture due to drought. It said that producing Aman at the north-western region of Bangladesh (Rajshahi division), required more fertilizers like urea, TSP and organics then the rest of the region).

Increasing input costs along with lesser soil fertility will cause less productivity of soil and thus will reduces benefits of the farmers in the region. As a result, farmers will become financially more vulnerable.

Less production due to drought in the north-western districts may also influence the market price for food grains, and cause food insecurity among the poor and ultra poor people of the country. 
Depletion of surface as well as ground water-level might necessitate installation of more deep tube-wells. This will increase the cost of irrigation for farmers.

Depletion of surface water level due to fall in the rate of precipitation in the region may hamper fish production. So people engaged particularly in the rapidly expanding cultured fisheries sector may find themselves jobless and their livelihood will be hampered, and thus making them economically more vulnerable.

Industries producing agricultural inputs, tools and machineries may also lose their business opportunities due to reducing agricultural activities. People working in those sectors may lose their jobs.

Furthermore, those industries which depend more on agricultural raw materials, have to import inputs from other countries due to reduced local supply; risking cost of production in further.

Loss in overall production may also lead to loss in revenue earning by local government and central government and may hamper the overall economic growth.

\section{Possible environmental impacts of drought in the north-western region of Bangladesh}

Besides economic backdrop, drought or drought-like phenomena in the north-western districts of Bangladesh may also cause environmental degradation, which may further affect people's lives and livelihood activities. These are as follows:

Degradation of soil quality of the region and thus affecting food production and soil biodiversity.

Loss of naturally produced food for fish species and wildlife.

Loss of habitats for fish and wildlife.

Less moisture and precipitation may create less favorable environment for flora and fauna of that region.

Drought may cause forced migration of wildlife as well as human being.

Loss of wetlands might be extensive due to water scarcity and thus loss of wetland based biodiversity and ecosystem.

Dust particles due to hot air temperature might pollute the environment and thus cause air-borne diseases for the people of the region.

\section{Conclusion}

Climatic indicators like high temperature and less rainfall are not only responsible for ground water depletion but availability of surface water is the major cause of depletion particularly in drought prone areas. So not only the ground water level depletion is the issue of concern, surface water availability is another major issue to address. Reduction of trans-boundary water movement is the primary reason of less availability of surface water. Both hydrologically and climatologically this region is vulnerable towards drought.

As ground water is used extensively for irrigation purpose, so water use efficiency should be increased and less water sensitive crops such as maize, pulse or oil seed crops cultivation should be increased. The government of Bangladesh should take immediate necessary measures to save the Barind region from becoming a barren region.

\section{References}

Adhikary SK, Das SK, Saha GC, Chaki T (2013) Groundwater Drought Assessment for Barind Irrigation. In: 20th International Congress on Modelling and Simulation

Agrawala S, Ota T, Ahmed AU (2003) Development and climate change in Bangladesh: focus on coastal flooding and the Sundarbans. Organisation for Economic Co-operation and Development (OECD), Paris

Ahmed AU (2005) Adaptation options for managing water-related extreme events under climate change regime: Bangladesh perspectives. In: Mirza MMQ, Ahmad QK (eds) Climate change and water resources in South Asia. Balkema Press, Taylor and Francis Group plc., The Netherlands

Ahmed AU (2006) Bangladesh climate change impacts and vulnerability. Climate Change Cell, Department of Environment Component 4b, Comprehensive Disaster Management Programme, Dhaka, Bangladesh

Australia Go (2003) Securing our water future: a state water strategy for Western Australia. Government of WA

Bari MF, Anwar AHMF (2000) Effects on irrigated agriculture on groundwater quality in northwestern Bangladesh. In: Proceedings of the integrated water resources management for sustainable development, Vol I, New Delhi, pp 19-21

Bates BZ (2008) Climate change and water. Technical Paper of the Intergovernmental Panel on Climate Change, vol 6. IPCC Secretariat, Geneva

BBS (2011) Population and housing census 2011: Bangladesh at a glance. Bangladesh Bureau of Statistics, Dhaka, Bangladesh

Chen ZS (2002) Predicting average annual groundwater levels from climatic variables: an empirical model. J Hydrol 260:102-117

Fatima Denton TW (2013) Climate-resilient pathways: adaptation, mitigation, and sustainable development. In: Bhadwal S (edn) IPCC, Fifth Assessment Report

Haji HT (2011) Impact of climate change on surface water availability. Department of Civil Engineering. Tshwane University of Technology

IPCC, WGI (2001) Climate change 2001: the scientific basis

IPCC, WGI, II, III (2007) Climate change 2007: synthesis report. Geneva, Switzerland

IPCC (2013) Climate-resilient pathways: adaptation, mitigation, and sustainable development. In: Denton F, Fifth Assessment Report, p 5-7

Kevin Johnston JM (2003) Using ArcGIS, geostatistical analyst. ESRI, United States of America

Neelormi AU (2008) Climate change, loss of livelihoods and forced displacements in Bangladesh: whither facilitated international migration? Centre for Global Change (CGC), Bangladesh 
Shahid S, Behrawan H (2008) Drought risk assessment in the western part of Bangladesh. Nat Hazards 46:391-413

UNESCO-CCPF (2011) Climate change impacts and adaptation strategies in the Yellow River Basin. Popular Science Press, Beijing
UN-Water, F (2007) Coping with water scarcity. Challenge of the twenty-first century. UN-Water

Watkins K (2006) Human Development Report. UNDP, New York 